\title{
Experimental testing of a low-temperature organic Rankine cycle (ORC) engine coupled with concentrating PV/thermal collectors: Laboratory and field tests
}

\author{
George Kosmadakis a, *, Arnaud Landelle b, c, d, 1 , Marija Lazova e, ${ }^{\text {, }}$, Dimitris Manolakos a , \\ Alihan Kaya ${ }^{\mathrm{e}}$, Henk Huisseune ${ }^{\mathrm{e}}$, Christos-Spyridon Karavas ${ }^{\mathrm{a}}$, Nicolas Tauveron ${ }^{\mathrm{b}}$, \\ Remi Revellin ${ }^{\text {c }}$, Philippe Haberschill ${ }^{\text {}}$, Michel De Paepe ${ }^{\mathrm{e}}$, George Papadakis ${ }^{\mathrm{a}}$ \\ a Department of Natural Resources and Agricultural Engineering, Agricultural University of Athens, Iera Odos Street 75, Athens 11855, Greece \\ b CEA, LITEN, DTBH, SBRT, LS2T, 17 rue des Martyrs, F-38054 Grenoble, France \\ ${ }^{c}$ Université de Lyon, INSA Lyon, CETHIL UMR5008, F-69621 Villeurbane, France \\ d ADEME, 20 Avenue du Grésillé, 49004 Angers, France \\ e Department of Flow, Heat and Combustion Mechanics, Ghent University, Sint-Pietersnieuwstraat 41, Ghent 9000, Belgium
}

\section{A R T I C L E I N F O}

\section{Article history:}

Received 27 April 2016

Received in revised form

12 August 2016

Accepted 17 October 2016

Available online 28 October 2016

\section{Keywords:}

Organic Rankine cycle

Concentrating PV/thermal

Low-temperature

Scroll expander

Evaporator

Diaphragm pump

\begin{abstract}
A B S T R A C T
A detailed experimental investigation of a small-scale low-temperature organic Rankine cycle (ORC) with $\mathrm{R}-404 \mathrm{~A}$ is presented. The tests are first conducted at laboratory conditions for detailed evaluation of the main components at both design and off-design conditions, for variable heat input up to $48 \mathrm{~kW}_{\text {th }}$ and hot water temperature in the range of $65-100{ }^{\circ} \mathrm{C}$. A scroll compressor in reverse operation is used as expansion machine and a dedicated helical coil heat exchanger is installed, suitable for high-pressure and temperature operation. The ORC pump is a diaphragm pump coupled with an induction motor. The rotational speeds of both the expander and pump are regulated with frequency inverters, in order to have the full control of the engine operation. The ORC has been then connected with concentrating PV/ thermal collectors, which produce electricity and heat and provide it to the ORC. These field tests are also presented with the overall focus on the performance of the whole ORC unit and its power contribution to the solar field. The tests have revealed that such low-temperature ORC unit can have adequate efficiency and that its coupling with a solar field is feasible, increasing the power production of the whole system.
\end{abstract} () 2016 Elsevier Ltd. All rights reserved.

\section{Introduction}

The organic Rankine cycle (ORC) technology is suitable for heat recovery applications of temperature even lower than $100{ }^{\circ} \mathrm{C}$ [1]. At such conditions its efficiency is rather low, usually in the range of $4-6 \%$, but still there are cases where it can be cost effective, especially for waste heat recovery. The main advantage at this temperature range is the simple and low-cost heat source circuit, since even liquid water can be used at low-pressure, while the use of thermal oil is avoided. Moreover, a simple ORC configuration can be considered with a single expansion machine and no internal heat exchangers [2,3].

\footnotetext{
* Corresponding author.

E-mail address: gkosmad@aua.gr (G. Kosmadakis).

URL: http://www.renewables.aua.gr/

1 Second and third author have equal contribution.
}

The challenge is even bigger in small-scale systems with power production of few $\mathrm{kW}$. In such cases although the design is rather simple to reduce costs, a very careful selection of each component is crucial, in order to keep an adequate performance. Moreover, lowtemperature operation (below $100^{\circ} \mathrm{C}$ ) brings some additional restrictions, since a limited number of organic working fluids can be used for such purposes. The most important components in ORC engines are: 1 . the ORC pump, for which low attention is given most of the times, 2 . the expansion machine with intensive research effort for producing/adapting expanders suitable for a wide power range (of positive displacement type or even turbines for larger systems), and 3. the evaporator, for which new correlations need to be developed for designing a heat exchanger suitable to operate in ORC conditions. When operating at low temperature, the condenser also becomes an important component, since thermal efficiency becomes highly sensitive to the temperature of the heat rejection medium. 
A list of existing experimental ORC units is shown in Table 1. This list only includes similar set-ups working with a heat source of $70-100{ }^{\circ} \mathrm{C}$ or an expander with inlet temperature under $100{ }^{\circ} \mathrm{C}$, and a heat input from 10 to $100 \mathrm{~kW}$ or an expander output power lower than $10 \mathrm{~kW}$. Most of them are dedicated to solar applications, but very few are finally tested when coupled with the solar field. Another common application in that range is the waste heat recovery (WHR). The organic fluids R134a, R245fa and R123 are the most common ones used. It is not easy and straightforward to compare bench performances, since there is no standard definition for power and efficiency.

Some main highlights can be extracted from Table 1. ORC units of that scale require low fluid flow rate and high pressure lift. Reciprocating pumps, such as diaphragm pumps, are widely used because they can handle such conditions, by providing constant flow rate regardless the pressure variation. Multistage centrifugal pumps are also used for such ORC units, but there are very few available references.

For small-scale systems with power production lower than around $20 \mathrm{~kW}$, scroll expanders have been widely used and showed adequate performance and expansion efficiency [20]. The present authors have also used the same expansion technology (both opendrive and hermetic ones) and revealed the good performance at a wide range of pressure ratios [1]. This brings confidence that such

Table 1

List of experimental small-scale low-temperature ORC (sorted by date).

\begin{tabular}{|c|c|c|c|c|c|}
\hline Info. & Heat source & Cold source & ORC fluid \& conditions & ORC components & Performances \\
\hline Reference & Heater & Cooler & Fluid (+Lubricant) & Pump (+Subcooler) & Exp. power \\
\hline \multirow[t]{2}{*}{ Target application } & Transfer fluid & Transfer fluid & Max - Min temperature & Evap. - Condenser (+IHE) & $\eta \mathrm{ORC}$ \\
\hline & Temp. - Power & Temperature & High - Low pressure & Expander - Output type & $\eta$ Carnot Cycle - Plant \\
\hline [4] & $\mathrm{n} / \mathrm{a}$ & Tap & R134a + Oil & Diaphragm & $3.3 \mathrm{~kW}(\mathrm{e})$ \\
\hline \multirow[t]{2}{*}{$\mathrm{n} / \mathrm{a}$} & Water & Water & $\mathrm{n} / \mathrm{a}-\mathrm{n} / \mathrm{a}$ & PHE - PHE & $\mathrm{n} / \mathrm{a}$ \\
\hline & $70{ }^{\circ} \mathrm{C}-\mathrm{n} / \mathrm{a}$ & $5^{\circ} \mathrm{C}$ & $\mathrm{n} / \mathrm{a}-\mathrm{n} / \mathrm{a}$ & Scroll Hermetic - El. AC & $\mathrm{n} / \mathrm{a}-{ }^{\mathrm{a}} 19 \%$ \\
\hline [5] & Gas & Air Chiller & N-Pentane & Diaphragm & $1.4 \mathrm{~kW}(\mathrm{e})$ \\
\hline \multirow[t]{2}{*}{ Solar } & Water & Direct & $81^{\circ} \mathrm{C}-31^{\circ} \mathrm{C}$ & $\mathrm{PHE}-\mathrm{n} / \mathrm{a}$ & $4.3 \%(\mathrm{e})$ \\
\hline & $93^{\circ} \mathrm{C}-34 \mathrm{~kW}$ & $31^{\circ} \mathrm{C}$ & 3.8 bar -1.1 bar & Turbine Radial - El. & ${ }^{\mathrm{a}} 14 \%-{ }^{\mathrm{a}} 17 \%$ \\
\hline [6] & Electric & $\mathrm{n} / \mathrm{a}$ & $\mathrm{R} 123$ & $\mathrm{n} / \mathrm{a}$ & $0.15 \mathrm{~kW}(\mathrm{~m})$ \\
\hline \multirow[t]{2}{*}{$\mathrm{n} / \mathrm{a}$} & Direct & $\mathrm{n} / \mathrm{a}$ & $70{ }^{\circ} \mathrm{C}-\mathrm{n} / \mathrm{a}$ & n/a - Shell-and-Tube & $1.2 \%(\mathrm{~m})$ \\
\hline & $\mathrm{n} / \mathrm{a}-13 \mathrm{~kW}$ & $\mathrm{n} / \mathrm{a}$ & $3.5 \mathrm{bar}-\mathrm{n} / \mathrm{a}$ & Turbine Radial - n/a & $\mathrm{n} / \mathrm{a}-\mathrm{n} / \mathrm{a}$ \\
\hline [7] & Engine Diesel & Tap & R134a + Oil & Diaphragm + Subcooler & $\mathrm{n} / \mathrm{a}$ \\
\hline \multirow[t]{2}{*}{ Solar \& WHR } & $\mathrm{n} / \mathrm{a}$ & Water & $\mathrm{n} / \mathrm{a}-\mathrm{n} / \mathrm{a}$ & PHE - PHE & $\mathrm{n} / \mathrm{a}$ \\
\hline & $83^{\circ} \mathrm{C}-80 \mathrm{~kW}$ & $7{ }^{\circ} \mathrm{C}$ & $\mathrm{n} / \mathrm{a}-\mathrm{n} / \mathrm{a}$ & Scroll Hermetic - El. & $\mathrm{n} / \mathrm{a}-{ }^{\mathrm{a}} 21 \%$ \\
\hline [8] & Solar + Gas & $\mathrm{n} / \mathrm{a}$ & HFE7000; N-Pentane & Diaphragm & $\mathrm{n} / \mathrm{a}$ \\
\hline \multirow[t]{2}{*}{ Solar \& Gas } & $\mathrm{n} / \mathrm{a}$ & Water & $67{ }^{\circ} \mathrm{C}-19{ }^{\circ} \mathrm{C}$ & PHE - PHE & $7.6 \%(\mathrm{e})$ \\
\hline & $70{ }^{\circ} \mathrm{C}-\mathrm{n} / \mathrm{a}$ & $\mathrm{n} / \mathrm{a}$ & 1.3 bar -1.2 bar & Turbine Radial - n/a & $14 \%-\mathrm{n} / \mathrm{a}$ \\
\hline [9] & Electric & Sea & $\mathrm{R} 134 \mathrm{a}$ & Diaphragm & $2.05 \mathrm{~kW}(\mathrm{~m})$ \\
\hline \multirow[t]{2}{*}{ Solar } & Water & Water & $\mathrm{n} / \mathrm{a}-\mathrm{n} / \mathrm{a}$ & PHE - PHE & $4 \%(\mathrm{~m})$ \\
\hline & $70{ }^{\circ} \mathrm{C}-100 \mathrm{~kW}$ & $25^{\circ} \mathrm{C}$ & $22 b-9 b$ & Scroll Open-Drive - El. & $\mathrm{n} / \mathrm{a}-{ }^{\mathrm{a}} 13 \%$ \\
\hline [10] & Solar & $\mathrm{n} / \mathrm{a}$ & R134a + Oil & Diaphragm & $1 \mathrm{~kW}(\mathrm{~m})$ \\
\hline \multirow[t]{2}{*}{ Solar } & Water & Water & $76{ }^{\circ} \mathrm{C}-35^{\circ} \mathrm{C}$ & PHE - PHE & $1.5 \%(\mathrm{~m})$ \\
\hline & $76{ }^{\circ} \mathrm{C}-80 \mathrm{~kW}$ & $\mathrm{n} / \mathrm{a}$ & $\mathrm{n} / \mathrm{a}-\mathrm{n} / \mathrm{a}$ & Scroll Open-Drive - Mech. & ${ }^{\mathrm{a}} 12 \%-\mathrm{n} / \mathrm{a}$ \\
\hline [11] & Solar + Electric & Cooling Tower & $\mathrm{R} 245 \mathrm{fa}$ & Diaphragm & $1.64 \mathrm{~kW}(\mathrm{~m})$ \\
\hline \multirow[t]{2}{*}{ Solar } & Direct + Water & Water & $78^{\circ} \mathrm{C}-14^{\circ} \mathrm{C}$ & $\mathrm{PHE}-\mathrm{n} / \mathrm{a}$ & $5.8 \%(\mathrm{~m})$ \\
\hline & $\mathrm{n} / \mathrm{a}-38 \mathrm{~kW}$ & $14^{\circ} \mathrm{C}$ & 6.7 bar 1.9 bar & Rolling-Piston - El. DC & ${ }^{a} 18 \%-n / a$ \\
\hline [12] & Solar & Cooling Tower & R245fa & $\mathrm{n} / \mathrm{a}$ & ${ }^{\mathrm{a}} 1.2 \mathrm{~kW}(\mathrm{a})$ \\
\hline \multirow{2}{*}{ Solar } & Glycol & Water & $90^{\circ} \mathrm{C}-25^{\circ} \mathrm{C}$ & Shell-and-Tube - PHE + IHE & $9 \%(a)$ \\
\hline & $90^{\circ} \mathrm{C}-10 \mathrm{~kW}$ & $\mathrm{n} / \mathrm{a}$ & 9.5 bar -1.4 bar & Rotary Vane $-\mathrm{n} / \mathrm{a}$ & ${ }^{\mathrm{a}} 18 \%-{ }^{\mathrm{a}} 25 \%$ \\
\hline [13] & $\mathrm{n} / \mathrm{a}$ & Cooling Tower & $\mathrm{R} 123$ & Centrifugal Multistage & ${ }^{\mathrm{a}} 2.4 \mathrm{~kW}(\mathrm{a})$ \\
\hline \multirow{2}{*}{$\mathrm{n} / \mathrm{a}$} & Oil & Water & $97{ }^{\circ} \mathrm{C}-20^{\circ} \mathrm{C}$ & PHE -PHE & $7.1 \%(a)$ \\
\hline & $\mathrm{n} / \mathrm{a}-\mathrm{n} / \mathrm{a}$ & $\mathrm{n} / \mathrm{a}$ & 6 bar -0.5 bar & Turbine Radial - El. DC & ${ }^{\mathrm{a}} 21 \%-\mathrm{n} / \mathrm{a}$ \\
\hline [14] & Electric & Cooling Tower & $\mathrm{R} 245 \mathrm{fa}+$ Oil & Plunger & $1.38 \mathrm{~kW}(\mathrm{e})$ \\
\hline \multirow[t]{2}{*}{ WHR } & Water & Water & $86^{\circ} \mathrm{C}-26^{\circ} \mathrm{C}$ & PHE - PHE & $7.8 \%(\mathrm{e})$ \\
\hline & $92{ }^{\circ} \mathrm{C}-{ }^{\mathrm{a}} 18 \mathrm{~kW}$ & $25^{\circ} \mathrm{C}$ & 8.5 bar -2.1 bar & Scroll - El. AC & ${ }^{\mathrm{a}} 17 \%-{ }^{\mathrm{a}} 18 \%$ \\
\hline [15] & Electric & Tap & $\mathrm{R} 134 \mathrm{a}$ & Plunger & 3.7 kW (e) \\
\hline \multirow[t]{2}{*}{ Solar } & Oil & Water & $88^{\circ} \mathrm{C}-26^{\circ} \mathrm{C}$ & PHE - PHE & $5.6 \%(\mathrm{en})$ \\
\hline & $\mathrm{n} / \mathrm{a}-63 \mathrm{~kW}$ & $10^{\circ} \mathrm{C}$ & 33 bar -7 bar & Scroll Hermetic - El. & ${ }^{\mathrm{a}} 17 \%-\mathrm{n} / \mathrm{a}$ \\
\hline [16] & Electric & Tank & R245fa & Diaphragm & $3.5 \mathrm{~kW}(\mathrm{e})$ \\
\hline \multirow[t]{2}{*}{ Solar } & Water & Water & $\mathrm{n} / \mathrm{a}-\mathrm{n} / \mathrm{a}$ & PHE - PHE & $7.2 \%$ (en) \\
\hline & $95^{\circ} \mathrm{C}-110 \mathrm{~kW}$ & $15^{\circ} \mathrm{C}$ & $\mathrm{n} / \mathrm{a}-\mathrm{n} / \mathrm{a}$ & Scroll Hermetic - El. AC & $\mathrm{n} / \mathrm{a}-{ }^{\mathrm{a}} 22 \%$ \\
\hline [17] & Gas & Tank & $\mathrm{R} 134 \mathrm{a}$ & Diaphragm + Subcooler & $5 \mathrm{~kW}(\mathrm{e})$ \\
\hline \multirow[t]{2}{*}{ WHR } & Water & Water & $88^{\circ} \mathrm{C}-33^{\circ} \mathrm{C}$ & PHE - PHE & $\mathrm{n} / \mathrm{a}$ \\
\hline & $90{ }^{\circ} \mathrm{C}-\mathrm{n} / \mathrm{a}$ & $15^{\circ} \mathrm{C}$ & 25 bar -9.5 bar & Scroll Open-Drive - El. AC & ${ }^{\mathrm{a}} 15 \%-\mathrm{n} / \mathrm{a}$ \\
\hline [18] & Gas & $\mathrm{n} / \mathrm{a}$ & R123 & $\mathrm{n} / \mathrm{a}$ & $0.4 \mathrm{~kW}(\mathrm{a})$ \\
\hline \multirow[t]{2}{*}{ WHR } & Water & Water & $89^{\circ} \mathrm{C}-\mathrm{n} / \mathrm{a}$ & Shell-and-Tube - PHE & $\mathrm{n} / \mathrm{a}$ \\
\hline & $90{ }^{\circ} \mathrm{C}-\mathrm{n} / \mathrm{a}$ & $\mathrm{n} / \mathrm{a}$ & 6.1 bar -0.7 bar & Rotary Vane - El. DC & $\mathrm{n} / \mathrm{a}$ \\
\hline [19] & $\mathrm{n} / \mathrm{a}$ & $\mathrm{n} / \mathrm{a}$ & $\mathrm{R} 245 \mathrm{fa}$ & Rotative Vane & $1.2 \mathrm{~kW}(\mathrm{a})$ \\
\hline \multirow[t]{2}{*}{$\mathrm{n} / \mathrm{a}$} & Water & Water & $90{ }^{\circ} \mathrm{C}-\mathrm{n} / \mathrm{a}$ & PHE - PHE & $9.3 \%(a)$ \\
\hline & $95^{\circ} \mathrm{C}-11 \mathrm{~kW}$ & $20^{\circ} \mathrm{C}$ & 10 bar -2.4 bar & Scroll - El. & $\mathrm{n} / \mathrm{a}-{ }^{\mathrm{a}} 20 \%$ \\
\hline
\end{tabular}

Expander power type: (e)lectric $=\mathrm{W}_{\mathrm{el}, \mathrm{exp}} ;(\mathrm{m})$ echanical $=\mathrm{W}_{\text {mech,exp }} ;(\mathrm{a})$ diabatic $=\mathrm{m}_{\mathrm{dh}} \mathrm{d}_{\mathrm{exp}}$.

$\eta$ ORC type: $($ en $)$ electric net $=\left(W_{\text {el,exp }}-W_{\text {el,pp }}\right) / Q ;(e) l e c t r i c=W_{\text {el,exp }} / Q ;(m)$ echanical $=W_{\text {mech,exp }} / Q ;(a) d i a b a t i c=m . d h$ exp $/ Q$.

$\eta$ Carnot: cycle $=1-\mathrm{T}_{\text {out,cond }} / \mathrm{T}_{\mathrm{in}, \mathrm{exp}}$; plant $=1-\mathrm{T}_{\mathrm{in}, \text { sink }} / \mathrm{T}_{\text {in,hot source. }}$

a Calculated by authors of this paper with data from the reference. 
expander can be even used at a supercritical cycle, which is the next step in this research. One positive aspect is that for lowtemperature applications, the pressure ratio is low and usually in the range of 2-4 [2], enabling the scroll expander to operate with good efficiency.

Concerning the evaporator, two types of heat exchangers (plate and shell-and-tube heat exchangers) have been mainly investigated for maximizing the net cycle efficiency of Organic Rankine Cycles [21,22]. However, there is a lack of experimental data regarding heat transfer in the evaporators, designed and suitable to work in ORC conditions. The researchers focus most of the times on optimization at system and component level, taking into consideration all possible heat exchangers for such applications. In order to predict the performance of the set-up at different operational conditions, system and component models have been developed [23]. Here, a helical coil design was selected as it could be produced in a cost-effective way for this prototype unit (more compact than a shell-and-tube heat exchanger) and easily integrated in the test setup. The performance of this component at subcritical state is reported in this work.

All previous research activities are very important especially in small-scale systems, in order to evaluate and compare the performance of the ORC. Here, an experimental study is implemented, testing a small-scale ORC with a net capacity of $3 \mathrm{~kW}$. The tests are first conducted in the laboratory with variable heat input and temperature $[24,25]$ for evaluating each key component and the ORC as a whole. Then, the ORC has been coupled with concentrating $\mathrm{PV} /$ thermal collectors. These collectors produce electricity from the PV cells and heat, which is provided to the ORC. The field tests during a winter and summer day are also presented and discussed.

\section{The installed ORC and concentrating PV/T collectors}

\subsection{The installed ORC engine at the laboratory}

The developed ORC engine has been installed at the laboratory for performance tests under controlled conditions. The heat input is provided by an electric heater and its heat production can be altered covering a large range of its capacity (from $25 \%$ of the total heat capacity: $12-48 \mathrm{~kW}_{\mathrm{th}}$ ) by operating different number of electric resistances and switching on/off the heater, keeping constant the hot water temperature. Different hot source temperatures have been examined from $65^{\circ} \mathrm{C}$ up to $100{ }^{\circ} \mathrm{C}$ with the heat transfer fluid (HTF) being pressurized water at around 2.5 bar at maximum temperature, and circulated with an inline centrifugal pump (Wilo IPL 32/160) at constant speed of $2900 \mathrm{rpm}$.

A simplified design of the system installed at the laboratory is depicted in Fig. 1, together with the heating and cooling circuits. Further details for the test-rig in the laboratory are provided in Ref. [25].

An electric brake (heavy duty unit, manufactured by Bonitron), is connected with the frequency inverter of the expander's induction motor, in order to control the test conditions and evaluate the performance of this expansion machine [25]. The engine cooling during the laboratory tests is accomplished with a cooling water circuit, using a conventional shell-and-tube heat exchanger. Cold water with a temperature of around $16{ }^{\circ} \mathrm{C}$ is circulated and drawn from a large water reservoir with capacity of $320 \mathrm{~m}^{3}$, rejecting the heat of the ORC engine (no cold water temperature increase was noticed during the whole testing period, keeping the heat rejection conditions constant). The condensation temperature of the organic fluid with this method is around $25^{\circ} \mathrm{C}$ (fluctuating according to the engine load).

The ORC pump is a triplex diaphragm pump manufactured by Hydra Cell (model G-10X), coupled with a $3 \mathrm{~kW}$ induction motor

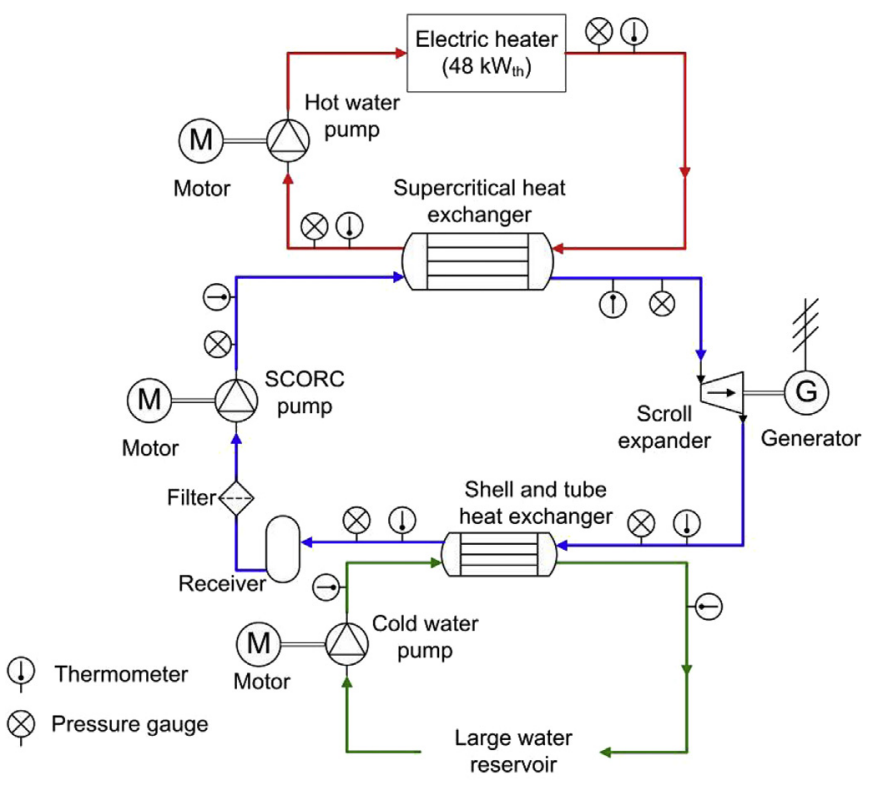

Fig. 1. ORC design (laboratory configuration).

(Valiadis K132S, 6-pole, 86.4\% nominal efficiency), driven by a $4 \mathrm{~kW}$ frequency inverter (Siemens SED2-4/32B).

The organic fluid selected is R-404A after screening many potential fluids using environmental (zero Ozone Depletion Potential - ODP), cost and efficiency criteria [25,26]. Although R-404a has a moderate Global Warming Potential (GWP), there is already a replacement fluid (R-407f) with similar properties but still high cost. Moreover, one of the biggest challenges was the modification of a commercial scroll compressor (Copeland ZP137KCE-TFD with swept volume of $127.15 \mathrm{~cm}^{3} / \mathrm{rev}$., maximum isentropic efficiency $75.2 \%$, and built-in volume ratio of around 2.8 at compressor mode) to operate as scroll expander (in reverse operation). A new casing had to be made, while many internal parts have been re-designed for better matching its operation as expander (such as the inlet volume before the fluid enters the steady scroll) [27]. The two scroll geometries have been kept the same (same built-in volume ratio as the original compressor).

An evaporator of a helical coil type with capacity of $41 \mathrm{~kW}$ has been developed for this application as well (Fig. 2). The shell of the helical coil heat exchanger is formed by two concentric cylinders in which a metal coil tube is fitted. The flow paths are arranged in counter flow with the hot water flowing downwards in the shell and the working fluid R-404A circulating upwards in the coil. The heat transfer between both fluids takes place across the coil wall. This evaporator is a key component in the installation, because it is the link between the ORC engine and the heat source. Such helical coil heat exchanger is designed and built specifically for such ORC installation, suitable to operate at relatively high pressure and temperature (capable for both sub- and supercritical working conditions) [28].

The ORC engine was installed in the laboratory and it is depicted in Fig. 2. All components have been mounted on the same structure and an electric panel is included. Further details are provided in Ref. [25].

\subsection{The installed CPV/T collectors with ORC}

The solar field has been installed at the AUA campus (in Athens, Greece). The field has been prepared (cleared and leveled) and the 10 collectors have been installed on concrete foundation. Each 


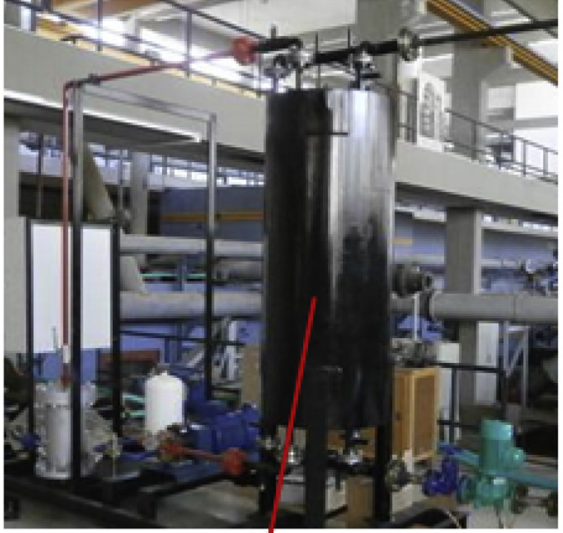

Evaporator

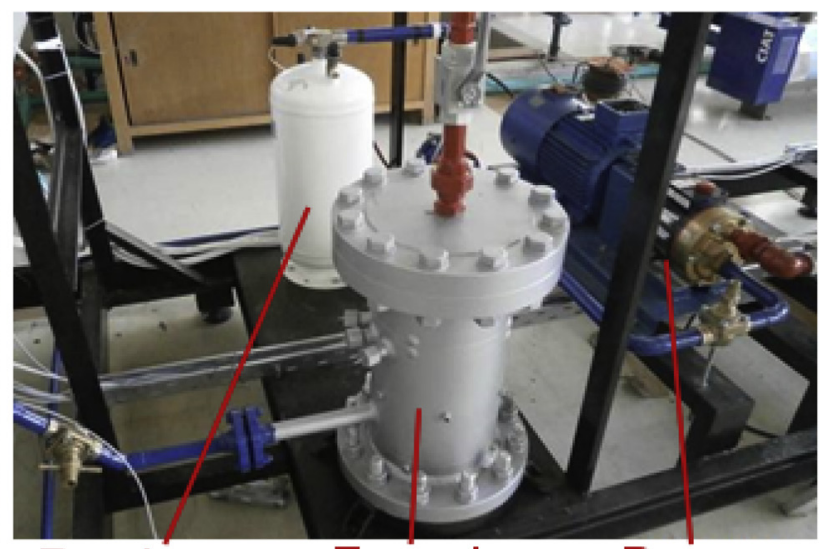

Receiver Expander
Pump

Fig. 2. ORC installed in the laboratory.

collector has electric capacity of $1 \mathrm{kWp}$, concentration ratio of around 10 , and heat production of $4.1 \mathrm{~kW}_{\mathrm{th}}$. They have been adapted to operate at temperature up to $95^{\circ} \mathrm{C}$ [24]. After finalizing the laboratory tests, the ORC engine has been moved to the field and connected with the piping circuit of the solar collectors. The solar field and the small housing, where the ORC is placed with all control and electric panels, are shown in Fig. 3.

The condenser of the ORC has been replaced with an evaporative condenser, for keeping the condenser pressure as low as possible, due to the pump inlet pressure limit of 17 bar. This condenser is also depicted in Fig. 3. An air-chiller is included in this set-up for dissipating the produced heat from the collectors in case the ORC is not operating (appropriate by-pass pipes and valves have been installed).

The main design of the combined system is shown in Fig. 4. A back-up electric heater is also mounted, in order to operate and test the ORC even if there is not adequate solar irradiation and heat production from the collectors.

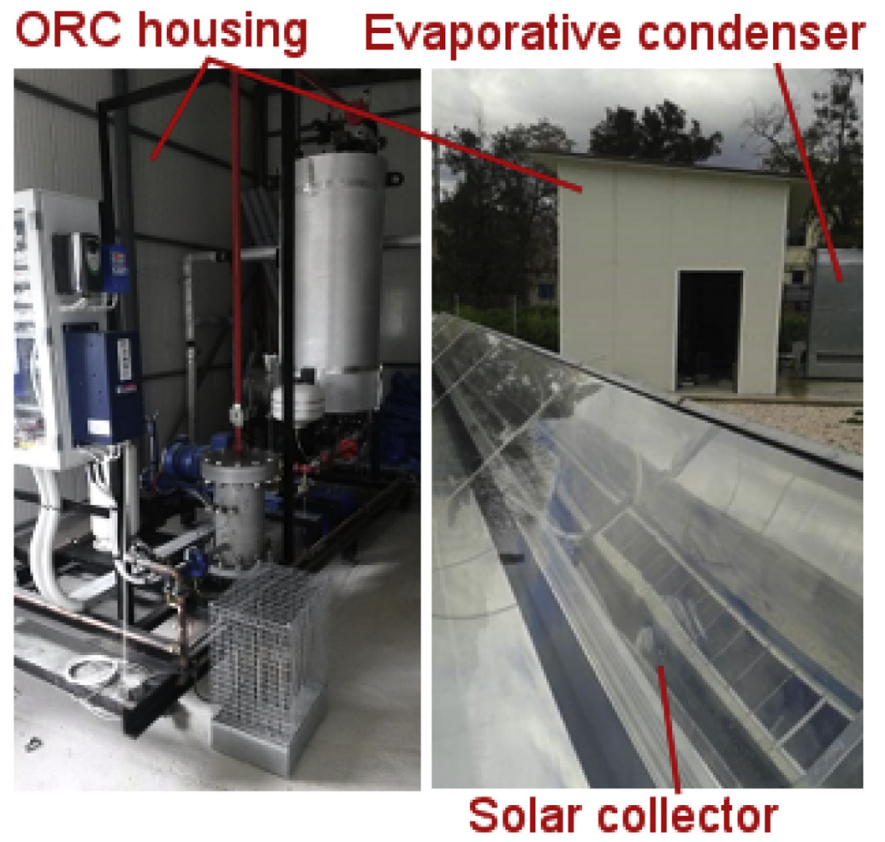

\subsection{Test data and processing}

The location of the measurement instruments is depicted at the three circuits in Fig. 1 (hot water circuit, ORC engine, cold water circuit), in order to measure the key properties and evaluate the performance of this engine at laboratory conditions. These instruments are mainly temperature and pressure sensors, in order to calculate the thermodynamic state of the organic fluid and hot/cold water at each location. The temperature sensors are of Pt100 type (accuracy up to $\pm 0.2{ }^{\circ} \mathrm{C}$ ), while the pressure transmitters are manufactured by Keller (type $21 \mathrm{Y}$ with measurement error up to $1 \%$ of the full scale). With the above uncertainties, the thermodynamic properties are calculated with an accuracy of around $1.2 \%$. Flow meters are not used, since steadystate conditions are examined, once the engine has reached a balanced operation at each case. The power production is measured directly from the expander frequency inverter. The heat input is calculated from the ORC side, since the organic fluid pump is of diaphragm type and has a linear correlation of flow rate with speed with a constant parameter of $0.0205(\mathrm{~L} / \mathrm{min}) / \mathrm{rpm}$, which provides a very reliable calculation of the volume flow rate (accuracy estimated at 2\%). The mass flow rate is then calculated with the measured temperature and pressure of the fluid at the pump outlet using EES/REFPROP database for R-404A [29]. The pump shaft speed and electric consumption are measured from the inverter.

The accuracy of the calculated parameters is given by the following expression [29]: $f_{t, t o t}=\sqrt{\sum_{i}\left(\frac{\partial t}{\partial X_{i}}\right)^{2} f_{t, i}^{2}}$. In Table 2 is given the relative measurement error for each main parameter (mean value), showing that it is low and would not influence the relative differences of the results.

The model of pump power balance proposed in Ref. [30] provides a very detailed understanding of losses and can suggest solutions for further improvements. This model is visualized in Fig. 5, including the motor and a variable speed drive (VSD).

The model parameters $C_{2}, C_{3}, C_{4} \& C_{5}$ are provided by pump and motor specifications. The Parameter $C_{1}$ is estimated from experiment, minimizing the error-objective function $F=$ $\sum\left(\dot{W}_{e l, m e a s}-\dot{W}_{e l, e s t i}\right)^{2}$, with electric power consumption given by: $\dot{W}_{e l}=C_{1}+\dot{W}_{\text {mech }}+C_{2} \cdot \dot{W}_{\text {mech }}^{2}+C_{3} \cdot \dot{\Omega}^{2}$ and hydraulic power by: $\dot{W}_{\text {mech }}=C_{4} \cdot \dot{\Omega}+C_{5} \cdot \dot{W}_{\text {hyd }}$.

Fig. 3. Solar field and ORC in the housing at the AUA campus. 


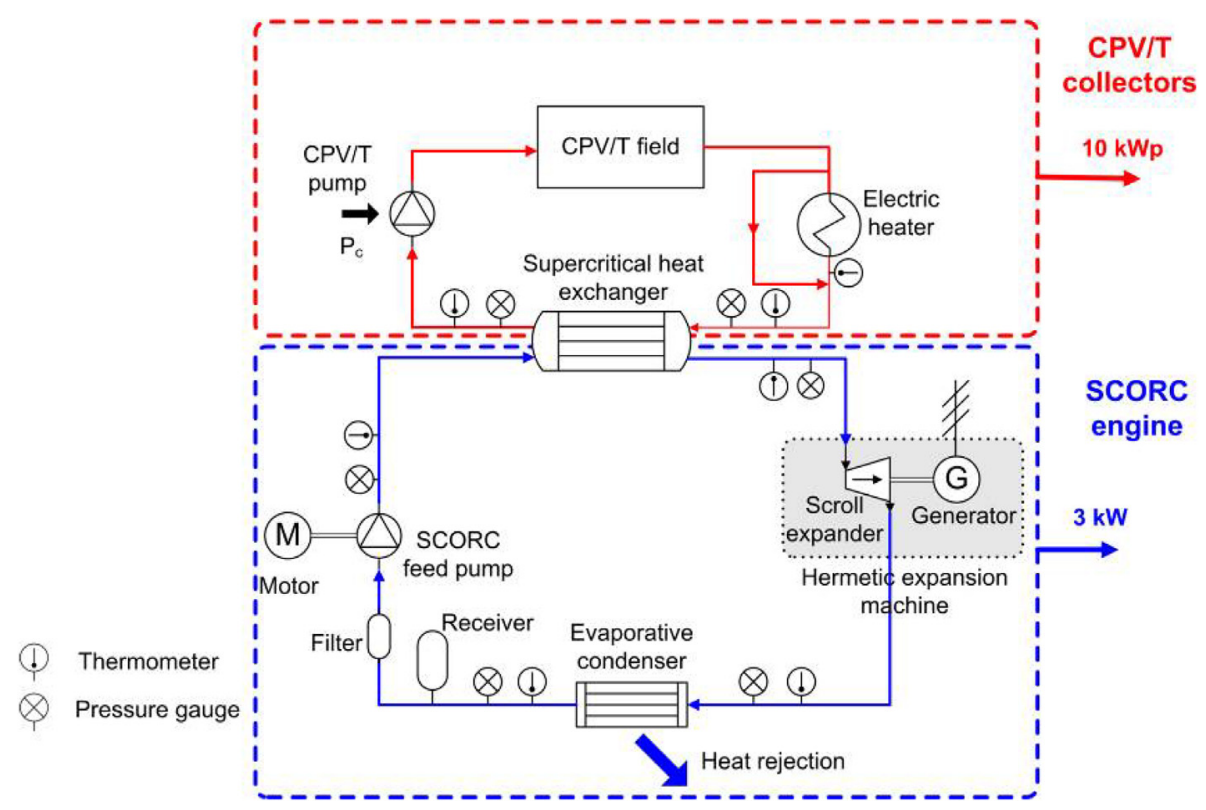

Fig. 4. Combined system (CPV/T with ORC) installed at the AUA campus.

Table 2

Accuracy of calculated parameters.

\begin{tabular}{llll}
\hline Parameter & Relative error (\%) & Range (Lab) & Range (Field) \\
\hline Heat input to ORC & 2.62 & $12-48 \mathrm{~kW}_{\text {th }}$ & $25-40 \mathrm{~kW}_{\text {th }}$ \\
Expander power production & 2.62 & $0.5-3 \mathrm{kWe}$ & $0.5-2 \mathrm{kWe}$ \\
Pressure ratio & 1.40 & $1.7-2.6$ & $1.4-2$ \\
Expansion efficiency & 2.66 & $20-85 \%$ & $65-75 \%$ \\
Thermal efficiency & 3.71 & $0-4.2 \%$ & $1-4 \%$ \\
\hline
\end{tabular}

\section{Results and discussion}

First, the laboratory tests are presented, leading to the validation of each main component and the whole ORC unit. Then, field tests are presented during winter and summer days.

\subsection{Laboratory tests}

Most of the tests in the laboratory have been conducted at subcritical operation. The hot water temperature varied from $65^{\circ} \mathrm{C}$ up to $100{ }^{\circ} \mathrm{C}$. The operating conditions that have been examined concern the variation of the ORC pump and expander speeds, which in turn affect the cycle and fluid properties. The ORC pump frequency is altered from $10 \mathrm{~Hz}$ up to $50 \mathrm{~Hz}(192-960 \mathrm{rpm})$ and the expander frequency is regulated from $10 \mathrm{~Hz}$ up to $45 \mathrm{~Hz}$ (580-2610 rpm). By regulating the pump speed, the heat input is varied up to almost $55 \mathrm{~kW}_{\text {th }}$, being almost linear, as presented with detail in Ref. [25]. In this way the heat input to the ORC can be controlled effectively, while at the same time the flow rate of the organic fluid is adjusted. The regulation of the organic fluid pump speed has an important effect on high pressure as well, especially when the expander speed is kept constant, as it will be shown later

\subsubsection{ORC pump}

The HTF temperature does not have any effect on the pump performance and therefore this parameter is not included in the pump analysis. The main parameters considered here are pressure difference and pump speed. The ORC pump has been investigated over a large range of pressure differences (in the range of 5.8-17.3 bar) and speeds (in the range of 384-864 rpm). The global efficiency of the pump is given by Eq. (1), while the hydraulic power by Eq. (2).

$$
\begin{aligned}
& \eta_{g, p p}=\dot{W}_{h y d, p p} / \dot{W}_{e l, p p} \\
& \dot{W}_{h y d, p p}=\dot{V} \cdot\left(P_{p p, o u t}-P_{p p, i n}\right)
\end{aligned}
$$

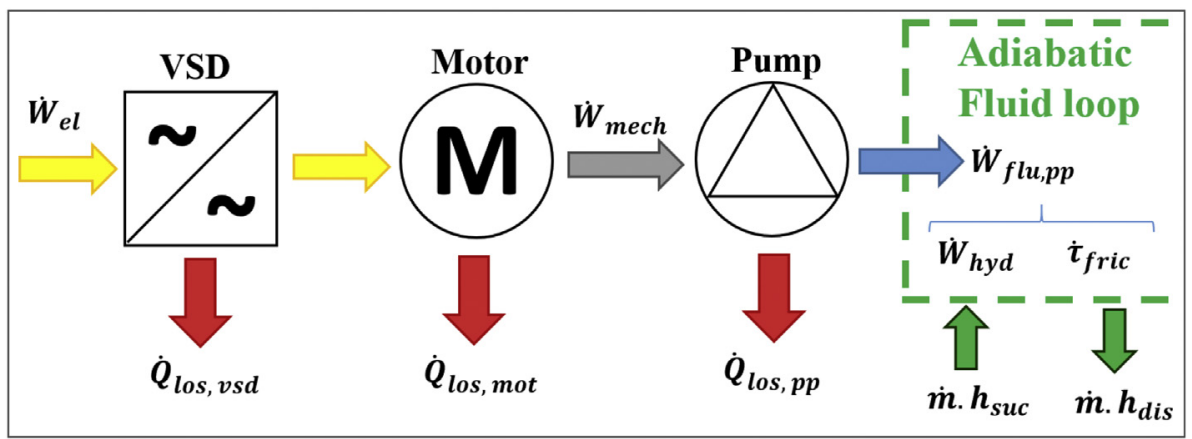

Fig. 5. Energetic chain of the pumping system with motor and VSD. 
The model of pump power balance has been then applied. The deviation between the measured electricity consumption $\left(\dot{W}_{\text {el.meas }}\right)$ and estimated one $\left(\dot{W}_{\text {el,esti }}\right)$ is less than 10\%, as shown in Fig. 6, while all parameters are provided in Table 3.

The maximum pressure difference imposed by the ORC at design conditions is 35 bar. According to pump manufacturer data, the maximum power required by the pump is $1.486 \mathrm{~kW}$ (35 bar, $960 \mathrm{rpm}$ ). Therefore, the motor rated power is two times the power requested for ORC maximum conditions. This oversize has been implemented, in order to provide the pump with adequate torque during starting, but has a negative impact on the efficiency, since the motor always operates below its nominal power by at least $50 \%$.

The pump global efficiency as a function of hydraulic power is presented in Fig. 7. The maximum pump global efficiency reaches
$32 \%$, for measured hydraulic power of $0.475 \mathrm{~kW}$.

Most of the losses are located in the driving part of the pumping system (inverter and motor) and represent $60-80 \%$ of the electric consumption. The static losses have been calculated to $883 \mathrm{~W}$, being as analogous to the value of $240 \mathrm{~W}$ obtained in Ref. [30] in a similar configuration, considering that the motor nominal power is two times higher and the inverter is not included in the motor (separate part). The induction motor operates between 5 and $20 \%$ of its nominal power (equal to $3 \mathrm{~kW}$, which has been deliberately oversized to have adequate power during supercritical operation) with efficiency much lower than its nominal one. The global pump efficiency could be higher in case of smaller motor sizing [31], but allows a smooth starting and adequate power during transient operation (important when the ORC is supplied with solar thermal energy).

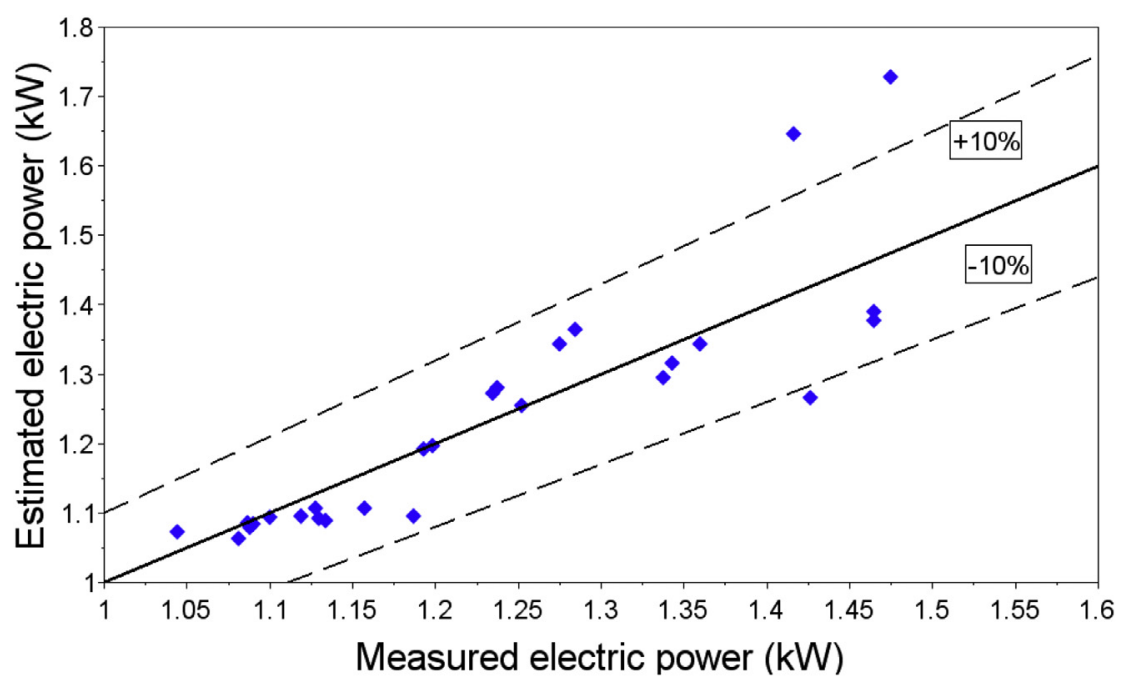

Fig. 6. Estimated vs. measured pump electric consumption.

Table 3

Parameters of the pump power balance model.

\begin{tabular}{|c|c|c|c|c|}
\hline & Equation & Parameter & Unit & Value \\
\hline Motor \& Variable Speed Drive (VSD) & $\dot{W}_{e l}=C_{1}+\dot{W}_{m e c h}+C_{2} \cdot \dot{W}_{\text {mech }}^{2}+C_{3} \cdot \dot{Q}^{2}$ & $\begin{array}{l}C_{1} \\
C_{2} \\
C_{3}\end{array}$ & $\begin{array}{l}\mathrm{W} \\
\mathrm{W}^{-1} \\
\mathrm{~W} / \mathrm{rpm}^{2}\end{array}$ & $\begin{array}{l}883 \\
3.67 \times 10^{-5} \\
1.54 \times 10^{-4}\end{array}$ \\
\hline Pump & $\dot{W}_{\text {mech }}=C_{4} \cdot \dot{\Omega}+C_{5} \cdot \dot{W}_{\text {hyd }}$ & $\begin{array}{l}C_{4} \\
C_{5}\end{array}$ & $\begin{array}{l}\text { W/rpm } \\
-\end{array}$ & $\begin{array}{l}0.178 \\
1.174\end{array}$ \\
\hline
\end{tabular}

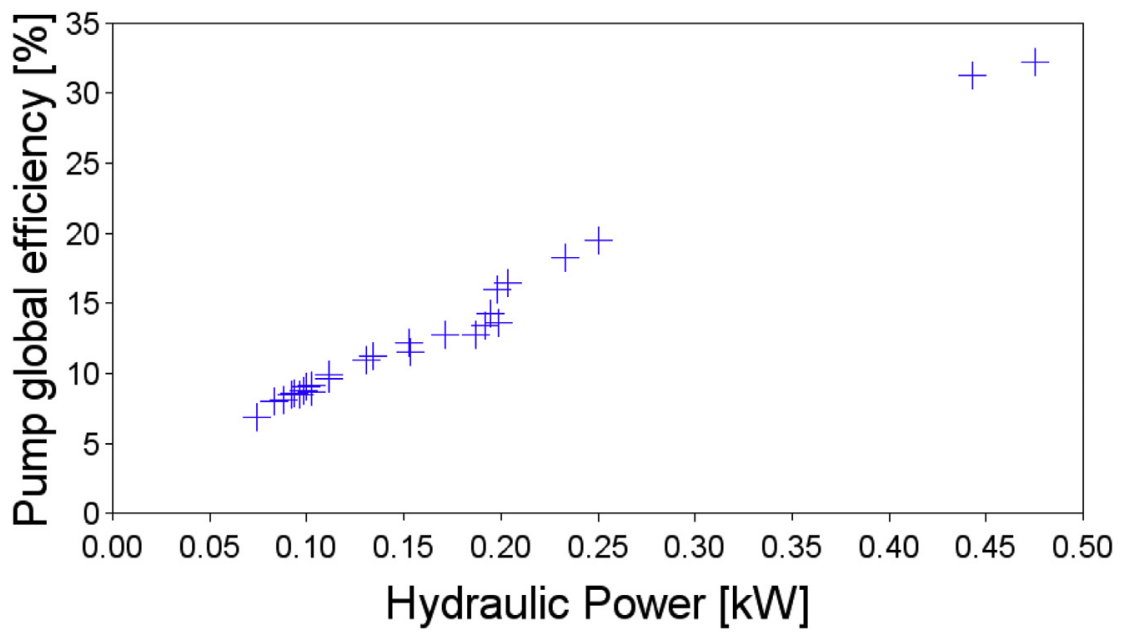

Fig. 7. Pump global efficiency as a function of hydraulic pumping power. 


\subsubsection{Evaporator}

The heat exchanger was designed for a heat transfer capacity of $41 \mathrm{~kW}$, inlet temperature of the heat transfer fluid of $95^{\circ} \mathrm{C}$ and mass flow rates of the HTF and the organic fluid of $2.5 \mathrm{~kg} / \mathrm{s}$ and $0.25 \mathrm{~kg} / \mathrm{s}$, respectively. Using the LMTD method, the design has been concluded. More details on the design procedure and the geometry can be found in Ref. [28].

The heat transfer is calculated from the measured data, using Eq. (3).

$Q=\dot{m}_{O R C}\left(h_{\text {evap }, \text { out }}-h_{\text {evap }, \text { in }}\right)$

where $Q$ is the heat transferred, $\dot{m}_{O R C}$ is the organic fluid mass flow rate, $h_{\text {evap,in }}$ and $h_{\text {evap,out }}$ are the enthalpies at the inlet and at the outlet of the evaporator.

Fig. 8 shows the heat transfer as function of the mass flow rate of the working fluid for different heat transfer fluid inlet temperatures. The heat transfer increases by increasing the mass flow rate in the coil, while keeping the mass flow rate constant at the annular (shell) side. A maximum value of the heat transfer of $55 \mathrm{~kW}_{\text {th }}$ is achieved at higher flow rates. The highest mass flow rate of $\dot{\mathrm{m}}_{\mathrm{ORC}}=0.34 \mathrm{~kg} / \mathrm{s}$ was reached at relatively low heating fluid temperature of $65^{\circ} \mathrm{C}$.

A comparison of the nominal designed value with the measurements was also possible. At the nominal mass flow rate of the organic fluid m $\dot{O R C}=0.25 \mathrm{~kg} / \mathrm{s}$ and HTF temperature of $95^{\circ} \mathrm{C}$ a heat transfer rate of $46 \mathrm{~kW}_{\text {th }}$ was achieved, which is higher than the designed one. The main reason for this difference is that the evaporator was designed for supercritical operating conditions using supercritical heat transfer correlations. Details about the heat transfer correlations that have been used for designing the heat exchanger are included in Ref. [28], while the development of new more accurate correlations is currently under investigation.

The pinch point temperature difference between the heating and organic fluid in the heat exchanger was then calculated. Since the temperature was measured only at the inlet and outlet of the heat exchanger, the thermal match profile was determined from a simple model developed in EES environment [29]. This thermal match for the three inlet measured temperatures for HTF temperature of $65^{\circ} \mathrm{C}, 80^{\circ} \mathrm{C}$ and $95^{\circ} \mathrm{C}$ is examined next.

Both the mass flow rate of the organic fluid and the inlet temperature at hot and cold side have a great influence on the pinch

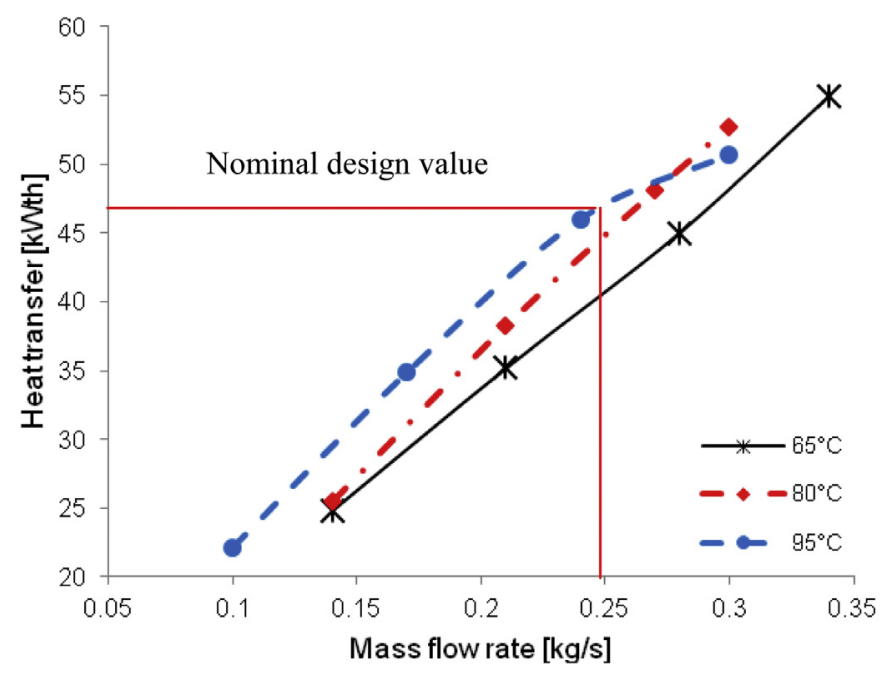

Fig. 8. Heat transfer as function of the mass flow rate of the organic fluid for different HTF temperature. point temperature difference. For all measurements the mass flow rate of the heat transfer fluid and the organic fluid R-404A was kept constant at $2.7 \mathrm{~kg} / \mathrm{s}$ and $0.3 \mathrm{~kg} / \mathrm{s}$ respectively. It is clear from Fig. 8 that an improved thermal match is obtained at higher mass flow rate of the organic fluid, approaching the design condition.

The inlet temperature of the organic fluid depends on its mass flow rate and the inlet temperature of the heating fluid. Hence, for inlet HTF temperature of $65^{\circ} \mathrm{C}$ the organic fluid's inlet temperature is $26{ }^{\circ} \mathrm{C}$. A minimum temperature difference of $13{ }^{\circ} \mathrm{C}$ is reached before the evaporation starts along the coil because the temperature difference of both fluids at the inlet of the heat exchanger is lower compared to the inlet temperatures of the HTF of $80^{\circ} \mathrm{C}$ and $95^{\circ} \mathrm{C}$, as presented in Fig. 9.

At higher temperatures at the hot side, for example at $95^{\circ} \mathrm{C}$, the temperature difference between both fluids and before the evaporation in the coil occurs is up to $36{ }^{\circ} \mathrm{C}$. This indicates that the exergy losses at such operating conditions are higher, due to the higher average temperature difference between the HTF and R404A.

By analysing the results from the measurements the pinch point temperature difference at the outlet of the evaporator is below $10{ }^{\circ} \mathrm{C}$, which is a lower value than the designed one. Hence, an improved thermal match at the outlet of the heat exchanger and pinch point temperature difference of only $2{ }^{\circ} \mathrm{C}$ is realized for all measurements due to the high superheating of the organic fluid.

\subsubsection{Scroll expander}

The expansion machine is directly coupled with a three-phase asynchronous motor/generator (capacity of around $10 \mathrm{~kW}$ ) inside the hermetic casing. This motor operates up to around one third of its nominal power, avoiding overheating, due to the absence of cooling (in compressor mode it is cooled by the organic fluid -usually a refrigerant- itself, which enters at low temperature).

The variation of both the pump and expander speed has a strong effect on electricity production and expansion efficiency. The power production is depicted in Fig. 10 for different pump speeds and HTF temperature as a function of pressure ratio. It should be noted that for constant pump speed, the pressure ratio is adjusted through the variation of expander speed, covering the whole expander speed range for high pump speed and a lower one (from 10 up to $25-30 \mathrm{~Hz}$ ) for low pump speed.

The maximum power production is equal to $3.2 \mathrm{~kW}$, and is observed for moderate pump speed (pump frequency equal to $35 \mathrm{~Hz}$ ) and pressure ratio (equal to 1.95) for HTF temperature of $95{ }^{\circ} \mathrm{C}$. But even for the moderate HTF temperature, the ORC engine shows high power production for a pressure ratio of around 2, due to the increased expansion efficiency at such conditions.

The maximum expansion efficiency is observed at a moderate expander speed/pressure ratio, due to the low electrical efficiency of the asynchronous generator at low speeds. In Fig. 11 is shown the expansion efficiency as a function of pressure ratio for the three different HTF temperatures. The expansion efficiency is calculated with Eq. (4) and includes all possible losses (electrical, friction, heat transfer, etc.) and provides a reliable evaluation parameter of all types of positive displacement expansion machines.

$n_{\text {ex }}=\frac{W_{\text {meas }}}{\dot{m}_{\text {ORC }}\left(h_{\text {exp }, \text { in }}-h_{\text {exp }, \text { out }, \text { is }}\right)}$

where $W_{\text {meas }}$ is the measured electricity production, $\dot{m}_{O R C}$ is the organic fluid mass flow rate, $h_{\text {exp,in }}$ is the enthalpy of the organic fluid at the expander inlet, and $h_{\text {exp,out }}$ is the enthalpy of the organic fluid at the expander outlet for isentropic expansion.

The maximum expansion efficiency is equal to $85 \%$ and is observed for a pressure ratio of 2 (for pump frequency of $35 \mathrm{~Hz}$ ), 

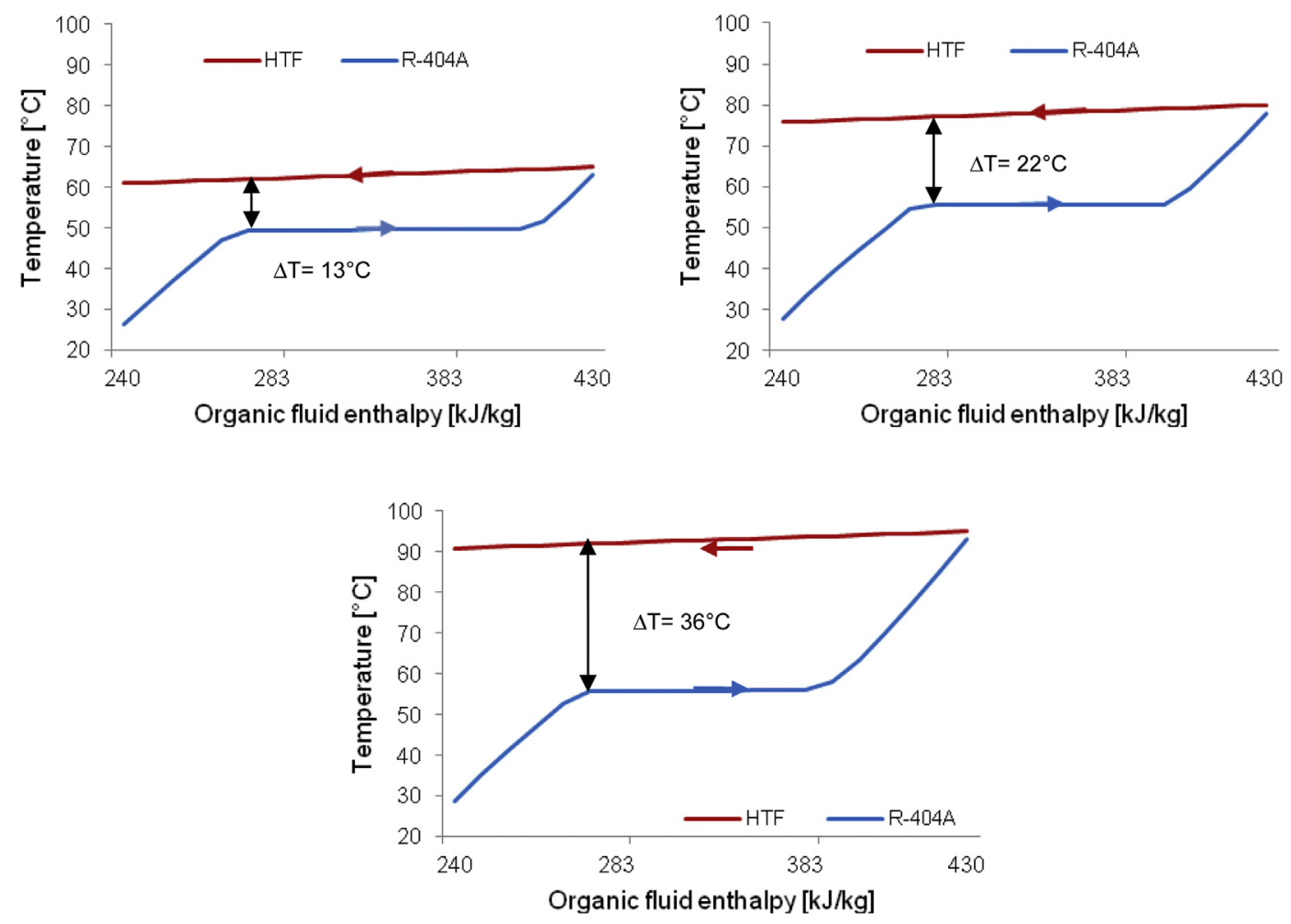

Fig. 9. Pinch point temperature difference for HTF temperature of 65,80 and $95{ }^{\circ} \mathrm{C}$.

which is highly relevant to the built-in volume ratio of the original compressor [32]. This optimum pressure ratio value is lower than in most of the ORC units (common pressure ratio values for maximum expansion efficiency are around 3-4 [33]), since the original compressor is intended for air-conditioning applications with R$410 \mathrm{a}$, where the pressure ratios are not very high (in the range of 2.5-3). For lower pump speeds and pressure ratios, the expansion efficiency is decreased. Moreover, as HTF temperature decreases, the maximum expander efficiency is observed for even lower pressure ratio (reaching even 1.65 for the $65^{\circ} \mathrm{C}$ case with an efficiency of up to $60 \%$ ). Finally, the expansion efficiency is, in general, higher for increased HTF temperatures, since at such conditions the volume ratio increases and approaches the built-in volume ratio of the expander, limiting under-expansion. A small improvement of volumetric efficiency can be also observed, which also aids the expansion efficiency increase.

The peak expansion efficiency is high and fully justifies the efforts for replacing the casing and optimizing some expander parameters, although for most of the operating conditions this efficiency is in the range of $45-70 \%$ and similar to other reported values for scroll expanders of similar scale and temperature $[9,14,20,34]$. Also, the selection of the ZP series of expansion machine with low built-in volume ratio (about 2.8 ) seems to be ideal for the specific application [35,36], since the pressure ratio is restricted to values around 2 for the R-404A fluid.

\subsubsection{ORC engine - energy analysis}

The thermal efficiency as a function of the pressure ratio is depicted in Fig. 12. The thermal efficiency is expressed as the net power output (power produced minus the ORC pumping work) divided by the heat input [37]. A maximum of $4.2 \%$ thermal efficiency is reached for a pressure ratio of 1.95 . At constant pressure ratio, ORC thermal efficiency increases with the expander speed, but a minor improvement is noticed above $30 \mathrm{~Hz}$. At constant expander speed, the thermal efficiency increases with the pressure ratio, which is directly related to the expander efficiency shown previously, with an optimum pressure ratio of around 2. However, such pressure ratio is only achieved for low expander speed. For high expander speed, the pressure ratio is limited by the pump maximum flow rate. Thermal efficiency of $5-6 \%$ could be expected for higher expander speeds, due to the decreased electrical losses in the expander induction generator.

\subsubsection{ORC engine - exergy analysis}

Exergetic efficiency is recommended for evaluation of lowtemperature power systems and comparison of their performance for different heat source temperature [38,39]. Exergetic efficiency expression depends on the heat source type and the application [40]. Solar applications can be considered as a sealed source type, and the exergy supplied to the ORC is determined by Eq. (5), with $\mathrm{T}_{0}$ the sink water inlet temperature in Kelvin.

$\Delta E_{\text {sup }}=\dot{m}_{H T F}\left[h_{H T F, \text { in }}-h_{H T F, \text { out }}-T_{0}\left(s_{H T F, \text { in }}-s_{H T F, \text { out }}\right)\right]$

The ORC exergetic efficiency is then defined as the net power output divided by the exergy supplied by the heat source: $W_{\text {net }} / \Delta E_{\text {sup }}$. The exergetic efficiency as a function of relative pressure for constant HTF temperature of $95^{\circ} \mathrm{C}$ is depicted in Fig. 13. The maximum exergetic efficiency increases with pump frequency and the optimum pressure differs with pump frequency. However, a reduced cycle efficiency at higher pressure is induced by the low expander speed (as a result of low expander efficiency). Considering only data with expander frequency above $25 \mathrm{~Hz}$, the exergetic efficiency constantly increases with the relative pressure.

For each heat source temperature $\left(65,80,95\right.$ and $\left.100{ }^{\circ} \mathrm{C}\right)$, the maximum exergetic efficiency points are presented and linked with the pressure-temperature map shown in Fig. 14, providing the exergetic efficiency value. This map can be used to conclude to the 

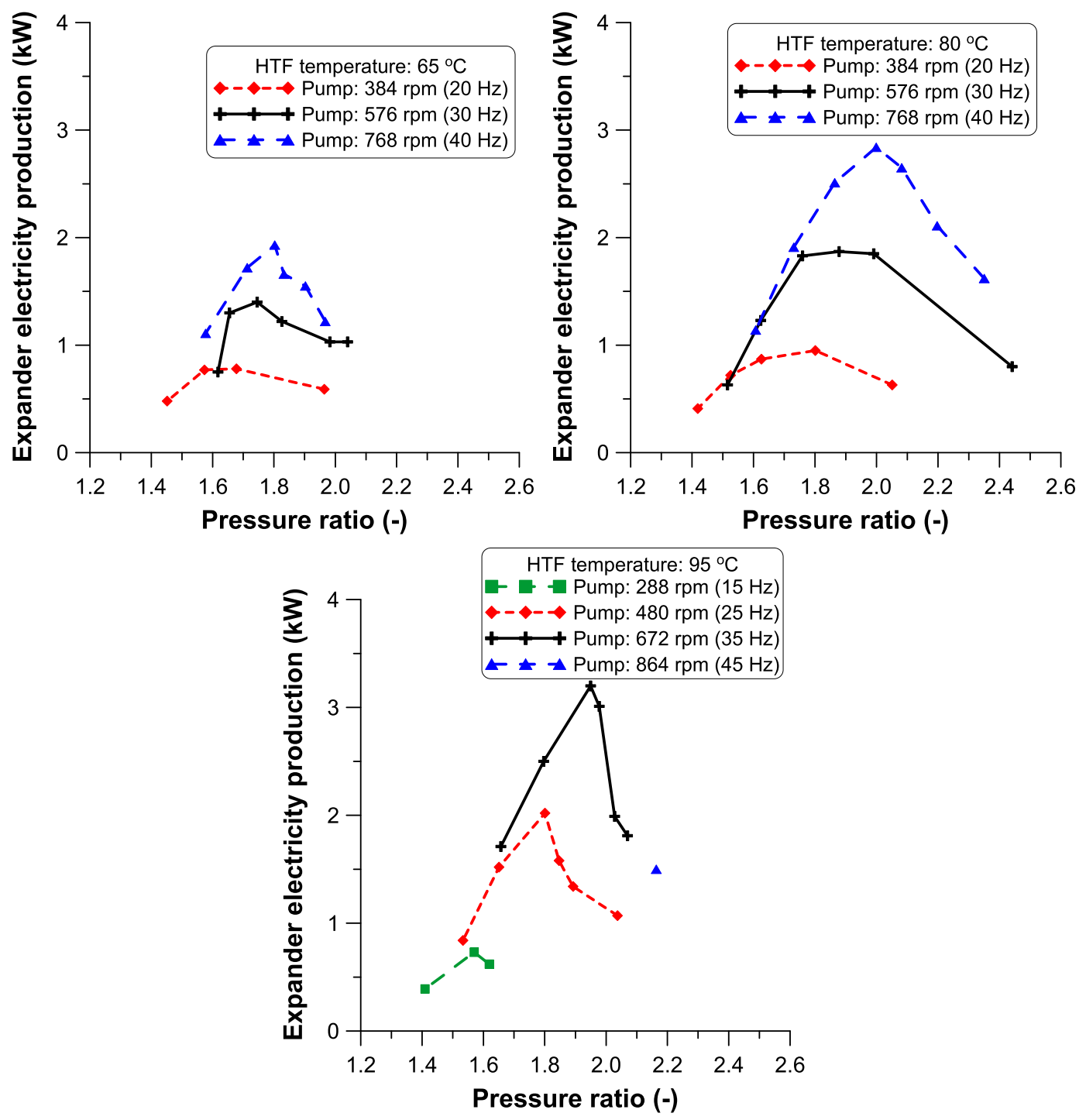

Fig. 10. Power production as a function of the pressure ratio for variable pump speed (HTF temperatures of 65,80 and $95{ }^{\circ} \mathrm{C}$ ).

optimum pressure of this specific set-up for different HTF temperature level according to the calculated exergetic efficiency. It can be observed that the optimum pressure is increasing with maximum temperature, but the optimum exergetic efficiency seems to be limited below $20 \%$.

Exergy analysis can be useful for each component of the ORC, concluding to an exergy flow diagram. Fig. 15 shows such diagram of: (a) the optimum subcritical point, and (b) transcritical point for similar supplied exergy of $9.1 \mathrm{~kW}$ (heat input: $43 \mathrm{~kW}_{\text {th }}$ at $95{ }^{\circ} \mathrm{C}$ ). The supplied exergy is used as a base index 100 for this figure.

Most of the exergy destruction occurs in the two heat exchangers (evaporator and condenser). The exergy loss in the evaporator occurs because of the high average temperature difference between the HTF and the organic fluid. In transcritical operation, the pressure is increased and the mean temperature difference is reduced. Therefore, exergy destruction in the evaporator is $30 \%$ lower for transcritical operation (see Annex). In the condenser, there is no valorization of the heat rejected. Even if superheating at the expander outlet is lower for transcritical case, condenser exergy destruction is $40 \%$ higher because the condensation pressure is 2.5 bar higher. Lower condensation pressure could be achieved with a better design and control of the condensation process. The use of an internal heat exchanger (IHE) for recovering the de-superheating power could save $10-30 \%$ of the heat input and reduce exergy destruction both in the condenser and evaporator.

Exergy destruction in the expander is much higher in the transcritical case, mainly because the expander frequency is very low $-15 \mathrm{~Hz}$ in average - in order to reach supercritical operation. Such operating conditions resulted in low expander efficiency as well, mainly due to the low electrical efficiency of the expander's generator.

At supercritical conditions the pump exergy destruction slightly increases by $15 \%$, while the provided hydraulic power is $60 \%$ higher than in the subcritical case. This is because of the high static losses in the pump power balance presented in Section 3.1.1.

\subsection{Combined solar field with ORC engine}

Next, the ORC engine has been moved to the field and connected with the CPV/T solar collectors. Tests have been conducted during winter and summer days, in order to examine and evaluate the combined system at different weather conditions. The main test results for both winter and summer days are presented next. 

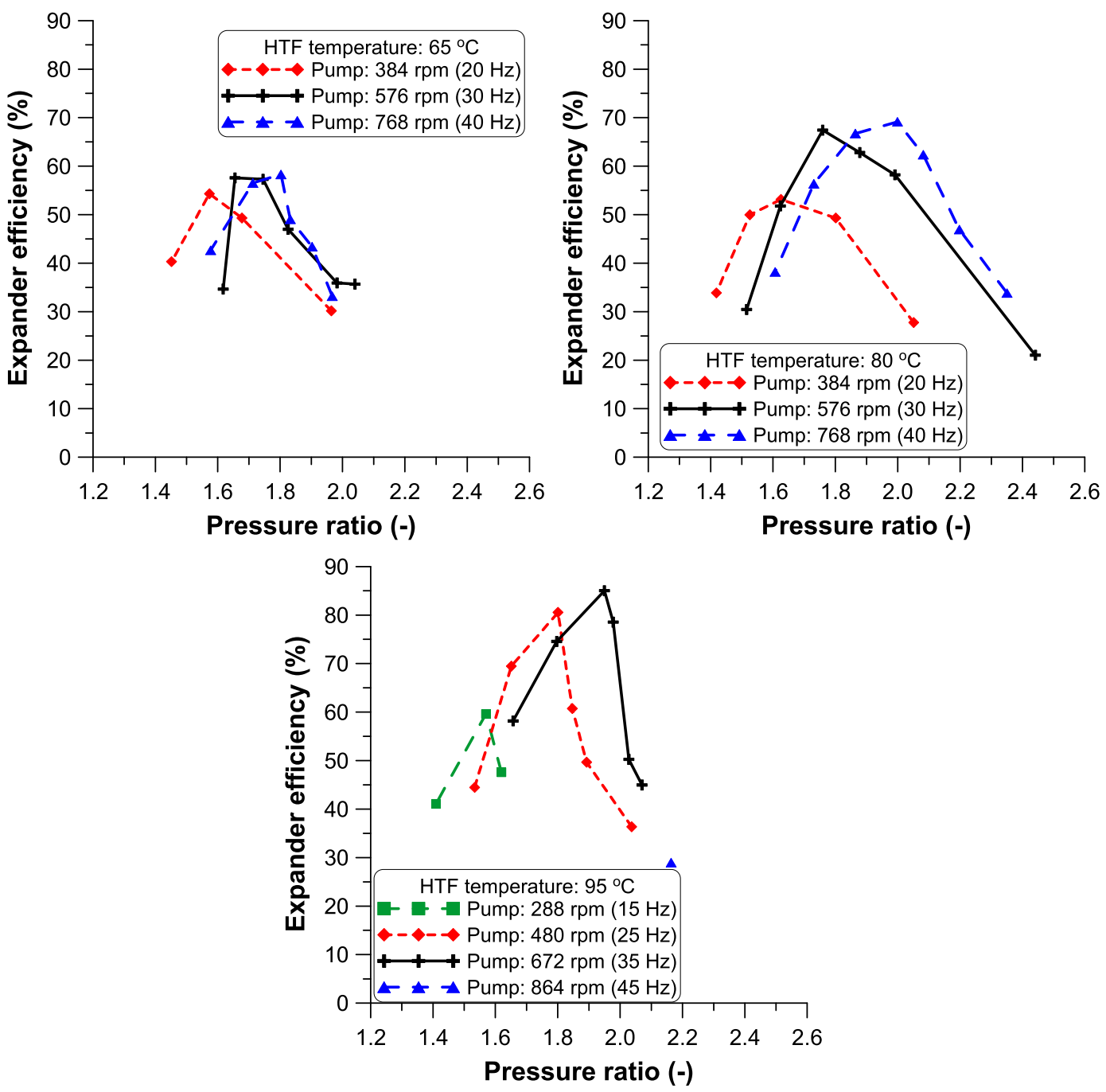

Fig. 11. Expansion efficiency as a function of the pressure ratio for variable pump speed (HTF temperatures of 65,80 and $95{ }^{\circ} \mathrm{C}$ ).

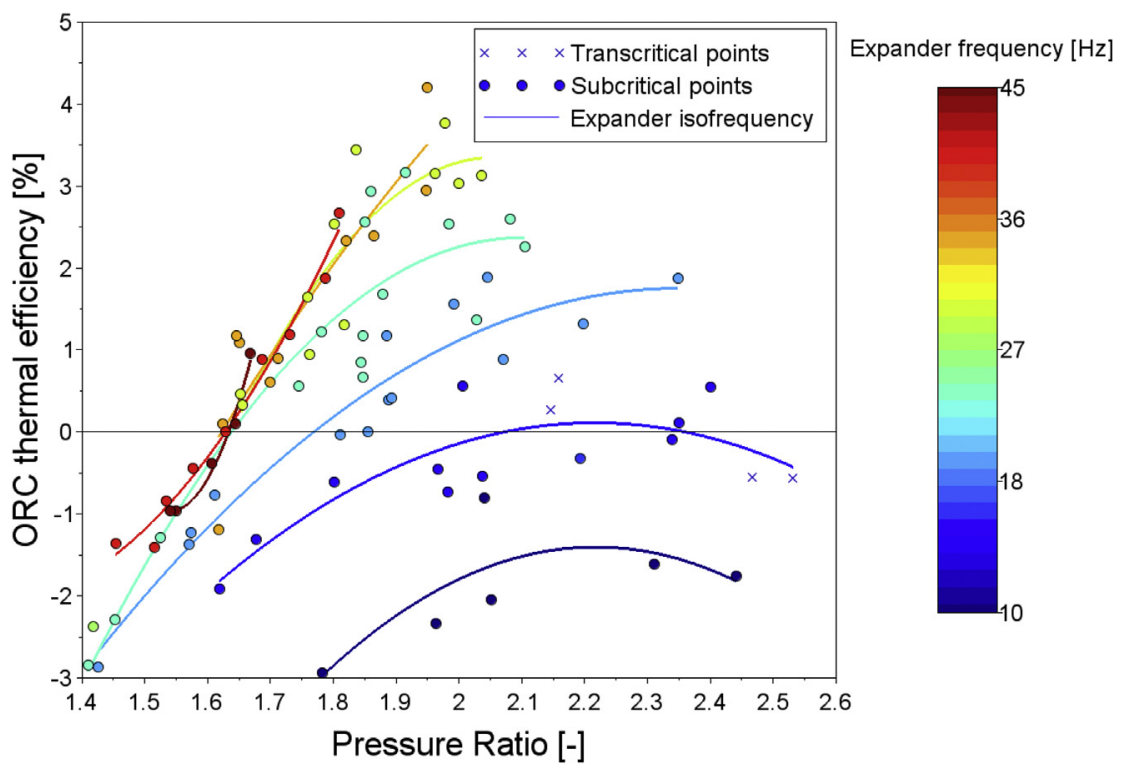

Fig. 12. ORC Thermal efficiency function of pressure ratio with expander iso-speed fitting. 


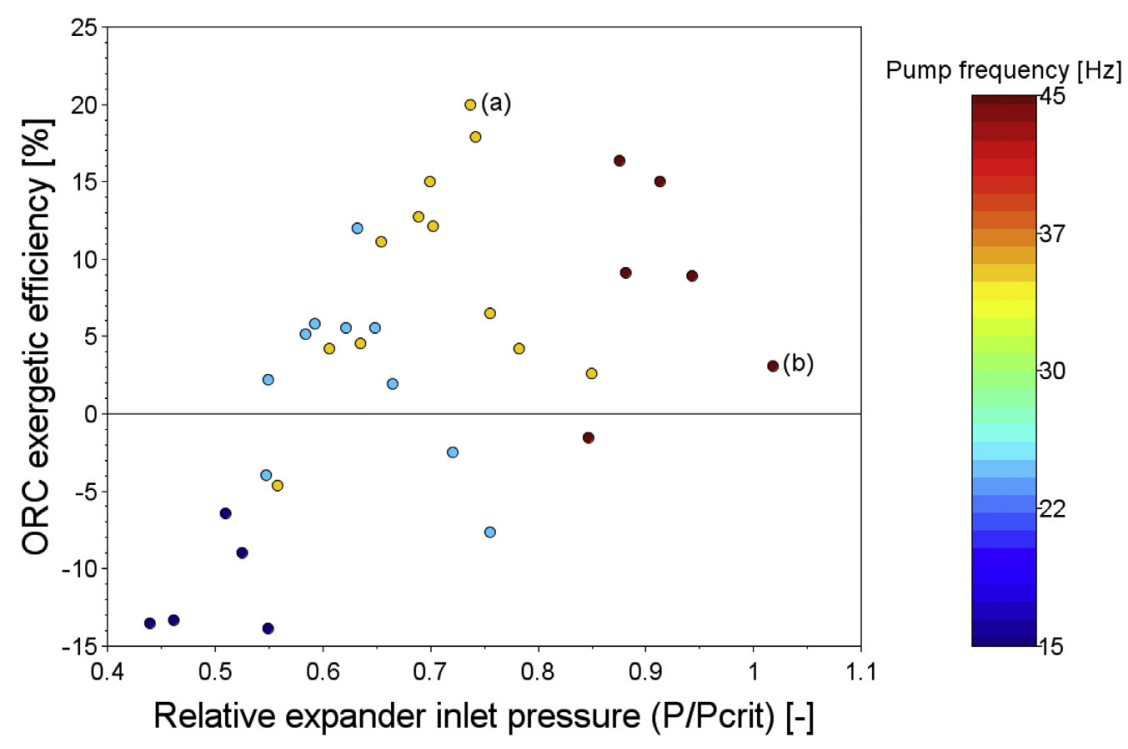

Fig. 13. ORC exergetic efficiency function of relative pressure for constant HTF temperature of $95{ }^{\circ} \mathrm{C}$.

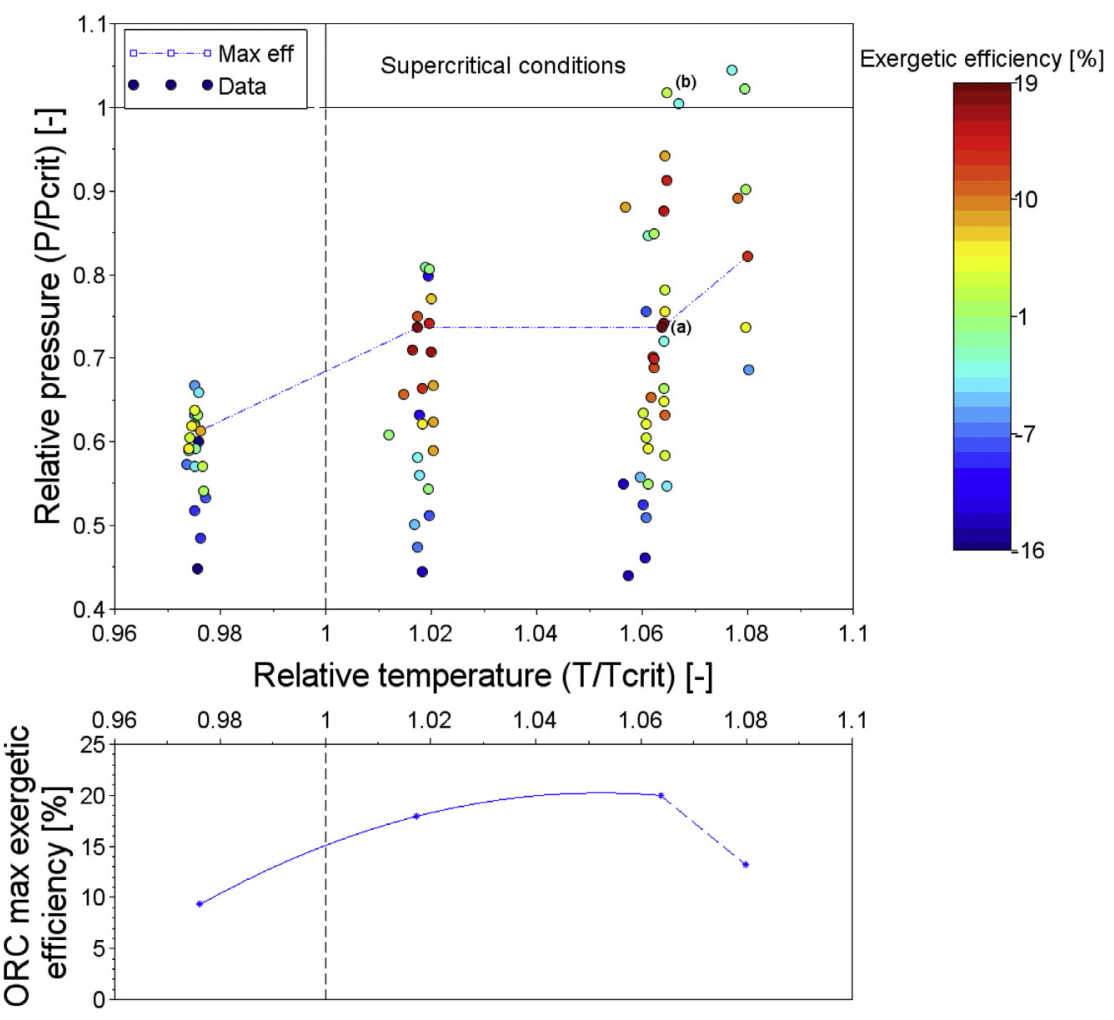

Fig. 14. Efficiency in the expander inlet relative pressure and temperature map.

\subsubsection{Winter tests}

The first performance tests of the combined system concern the operation for almost steady state conditions during a sunny winter day. The HTF pump speed is decreased (pump frequency of $30 \mathrm{~Hz}$ ), in order to reach higher temperatures, due to the moderate solar irradiation.

In Fig. 16 is shown the heat produced by the collectors, the heat provided to the ORC, and the HTF temperature. Until around 12:15 the system load was increasing, due to the sunshine and the heat produced was up to $40 \mathrm{~kW}$ (heat produced by collectors and absorbed by ORC is almost equal with minor differences). The heat provided to the ORC then continues to increase due to the high thermal inertia of the evaporator, while the heat produced by the collectors is decreased, due to the high HTF temperatures and higher thermal losses from the collectors. Nevertheless, during the whole test duration the operation is more or less stable with few fluctuations, which makes it possible to evaluate the combined system.

The HTF temperature is increased slightly over $70{ }^{\circ} \mathrm{C}$ and the HTF temperature difference (inlet/outlet difference) is around $5 \mathrm{~K}$. 


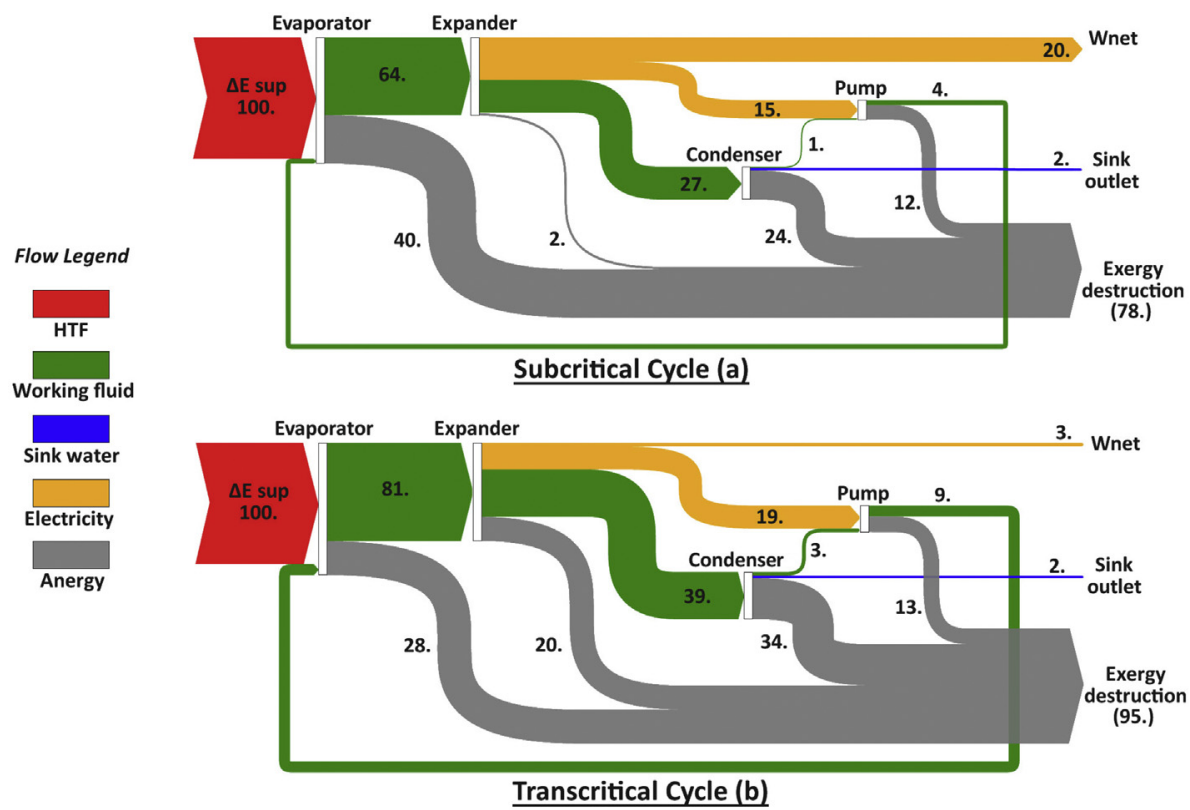

Fig. 15. Exergy flow - comparison between optimum subcritical and transcritical cycle.

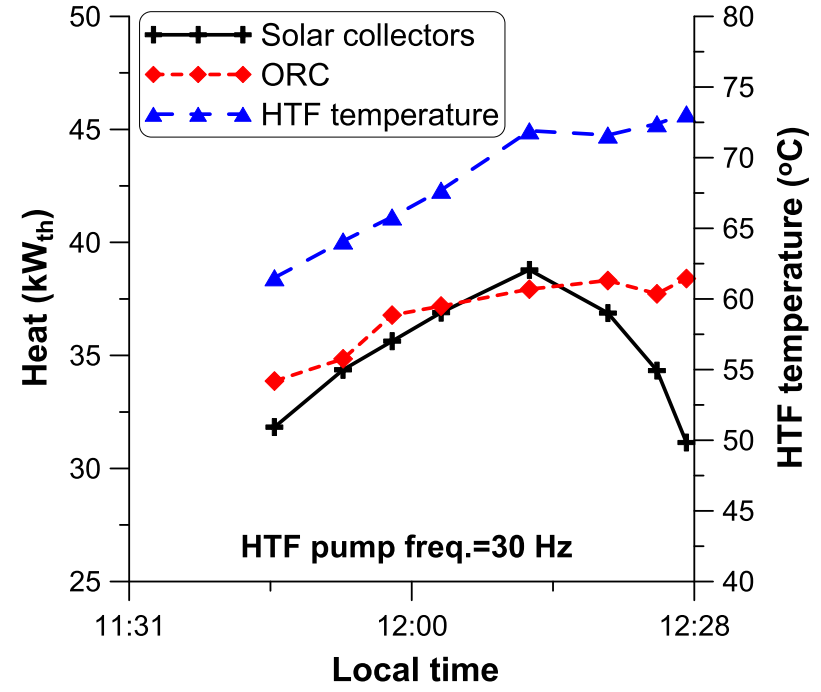

Fig. 16. Heat produced by the collectors and absorbed by the ORC and HTF temperature during the winter day.

For the whole test duration the HTF temperature varies from $60^{\circ} \mathrm{C}$ up to $72^{\circ} \mathrm{C}$.

As the HTF temperature increases, so does the organic fluid temperature and pressure. The pressure at the expander inlet increases during this test period (see left Fig. 17), whereas the expander pressure ratio, decreases, due to the increased cooling load of the condenser (the condensation pressure is increased). In the same figure the performance of the ORC engine (expander and cycle thermal efficiency) at such almost stable conditions is also presented, together with the electric power production from the ORC and the PV cells.

The efficiency of the expander reaches even $74 \%$, while it holds high values for the whole test duration (in the range of $65-70 \%$ ). Similar conclusions have also been drawn during the laboratory tests, as presented in the previous sections. The high expander efficiency brings an increased thermal efficiency as well, since the maximum reached is almost $4.6 \%$. During the end of the testing period, the thermal efficiency drops, due to the increased condenser pressure.

Moreover, since solar irradiation was almost constant during this period, the PV production is almost constant as well and equal to around $5 \mathrm{~kW}$. The ORC engine production is also stable and around $1.9 \mathrm{~kW}$, while during the end of these tests it starts to decrease, as already mentioned. The net power production of the ORC is lower due to the pump consumption, which is almost $1 \mathrm{~kW}$. The ORC engine net production is around $20 \%$ of the PV production, which increases the productivity of the combined system at such conditions.

\subsubsection{Summer tests}

The combined system has been also tested during different summer days. In this section the test results during one representative summer day are presented.

The heat produced by the collectors, the heat provided to the ORC, and the HTF temperature values are shown in Fig. 18. There is high fluctuation of the heat produced and absorbed by the ORC, since the system operates at unsteady conditions.

The heat provided to the ORC is mostly in the range of 20-40 $\mathrm{kW}_{\text {th }}$, while the HTF temperature reaches even $80^{\circ} \mathrm{C}$. After $12: 30$ it is reduced due to few clouds that did not allow it to further increase heat production and temperature.

The expander inlet pressure and pressure ratio are shown in Fig. 19. The pressure level is now much higher than during the winter day, due to the higher condenser pressure, which shifts the whole cycle to higher pressure. This brings a lower pressure ratio (around 1.6), which is not beneficial for the expander, as also shown in Fig. 19 (right).

The efficiency of the expander reaches 65\% and then it is reduced to even $30 \%$, leading to low thermal efficiency in the range of $1-3.5 \%$. An encouraging aspect is that even during transient operation the ORC engine can maintain an adequate performance, showing that it is suitable for such conditions. Moreover, PV production is much lower than in the winter day, due to the high ambient temperature, which also has a negative effect on ORC production (due to high condenser pressure), resulting to low power production and much lower than in the winter day. 

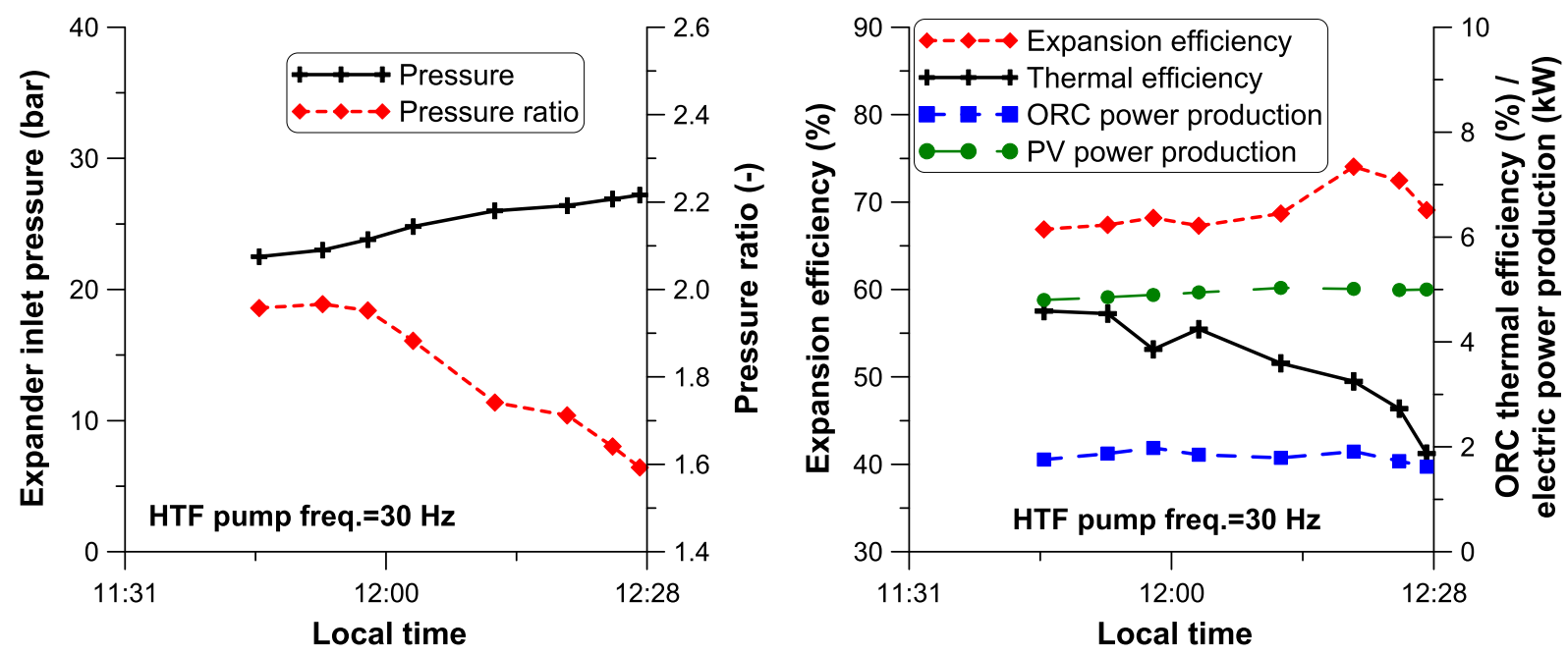

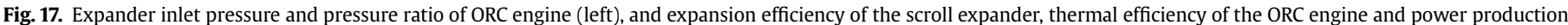
(right) during the winter day.

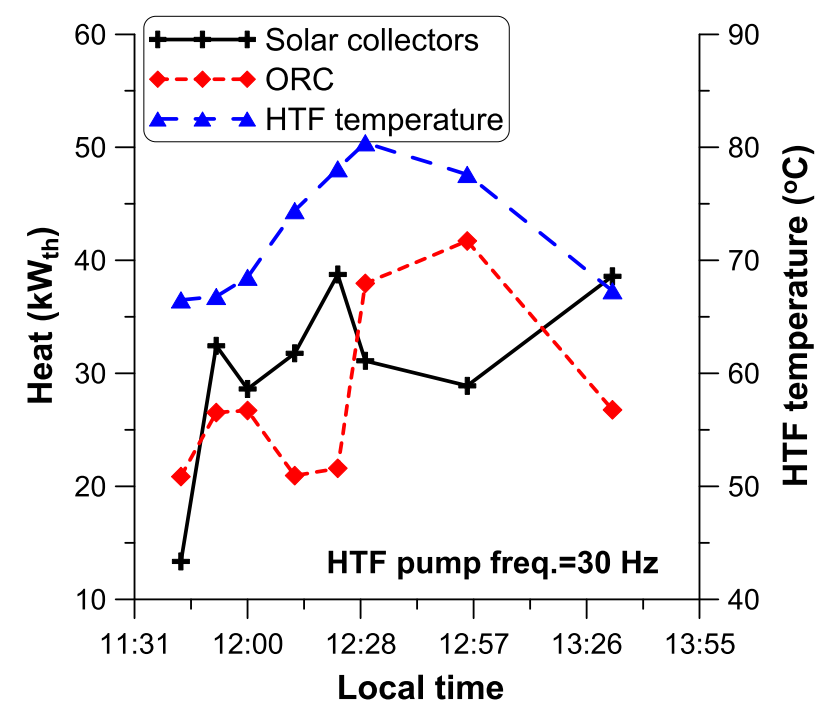

Fig. 18. Heat produced by the collectors and absorbed by the ORC and HTF temperature during the summer day.

\section{Conclusions}

The detailed experimental results of the ORC engine testing at the laboratory have been presented, revealing its performance capability and evaluating its main components (pump, evaporator, and expander). The tests concern a large range of HTF temperature with variable heat input. Various parameters have been examined, mainly when regulating the expander and pump speed, showing the heat-to-power conversion efficiency of such engine. A detailed energy and exergy analysis is presented, focusing on the main components.

The pump global efficiency is low, as expected, while the expander efficiency can reach high values at a small range of operating conditions. Also, the evaporator outperforms in terms of the heat transferred and the pinch point temperature difference at the outlet of the heat exchanger, showing that more accurate correlations need to be developed, for even more detailed designs and use of less material (leading to lower costs). The most important conclusions from the laboratory tests is that such ORC engine with capacity of just $3 \mathrm{~kW}$ can reach an adequate thermal efficiency, when operating at very low temperature.
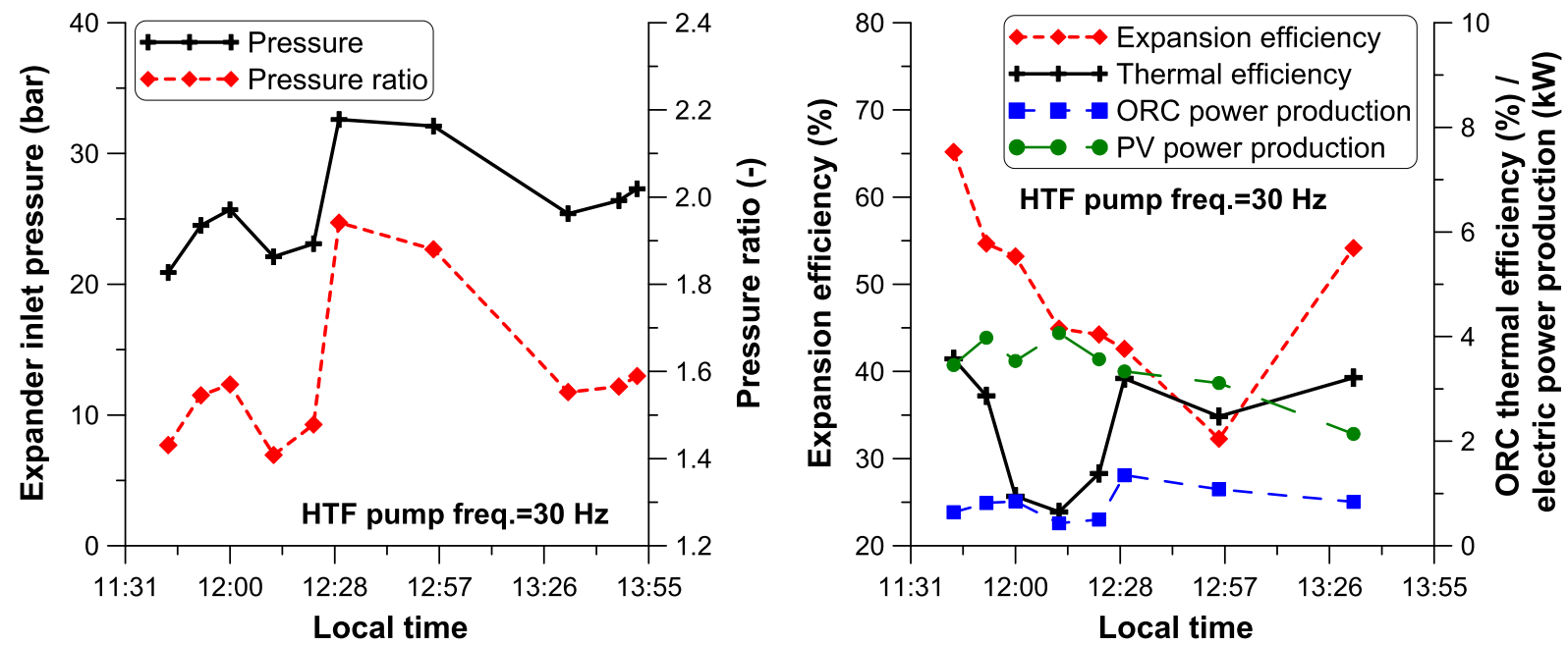

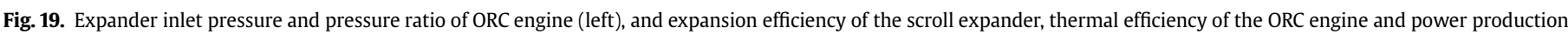
(right) during the summer day. 
The ORC engine has been then coupled with concentrating PV/T collectors, which provide the heat produced to the ORC. Various tests have been conducted during both winter and summer day, to demonstrate the performance of the combined system. The ORC engine could operate with good performance even at unsteady conditions, increasing the productivity of such hybrid system during both winter and summer day.

In the present study experimental test data are presented and evaluated, and the advantages and the potential of such technology could be identified. Also, some first proof is provided, whether such combined system can increase power production, by utilizing the available low-temperature heat. Nevertheless, a

\section{Annex}

Exergy destruction rate in the evaporator is defined as the exergy destruction divided by the exergy supplied. There is a strong correlation with the evaporation pressure and the maximum temperature (see Fig. A-1). When pressure is increasing, exergy destruction rate decreases, because the mean temperature difference between HTF and working fluid is decreased. But when the heat source fluid temperature increases, and so does the maximum cycle temperature, the destruction rate in the evaporator is also increased. This is because the mean HTF temperature increases faster than the working fluid mean temperature.
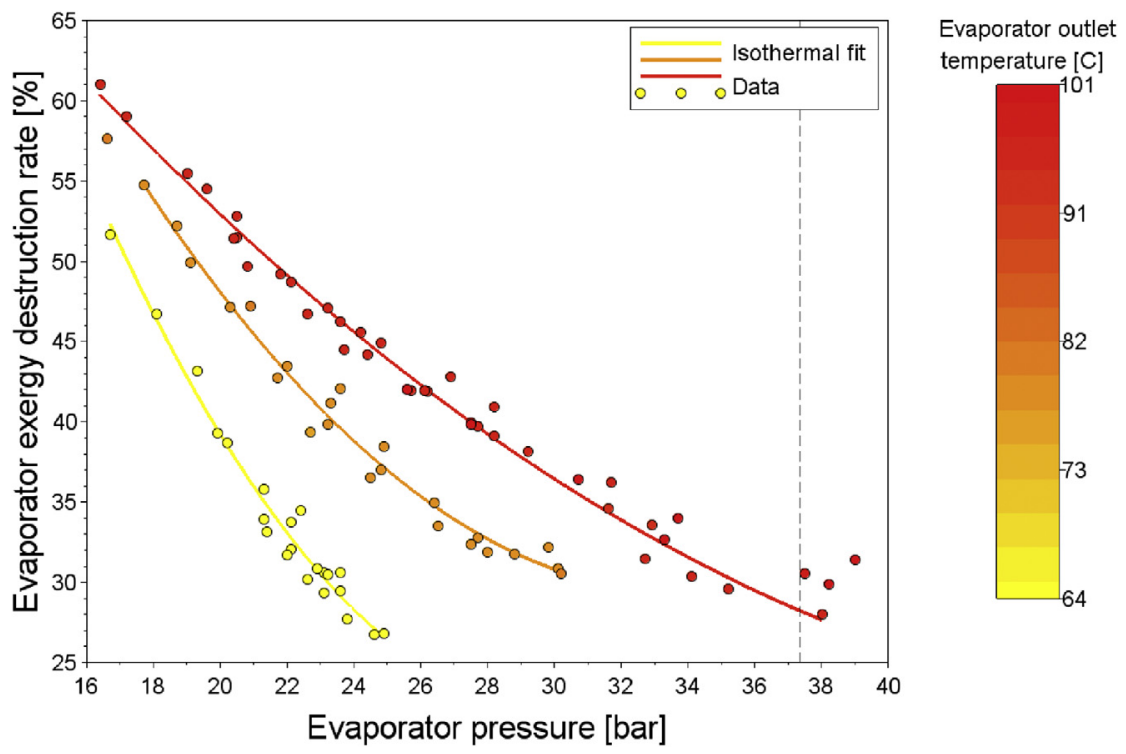

Fig. A-1. Exergy destruction rate in the evaporator.

detailed techno-economic study is required, in order to identify the advantages of the presented system in comparison with other ORC units coupled with solar thermal collectors and operating under similar conditions (mostly relevant to HTF temperature), since for the same collectors' area the system produces more electricity (from both the PV cells and the ORC), but its cost is also higher.

\section{Acknowledgements}

The research leading to these results has received funding from the European Union's Seventh Framework Programme managed by REA-Research Executive Agency, http://ec.europa.eu/research/rea ([FP7/2007-2013] [FP7/2007-2011]) under grant agreement $\mathrm{n}^{\circ}$ 315049 [CPV/RANKINE], FP7-SME-2012. The AUA and UGENT research teams would also like to thank their partners for their work within this project.

A part of this work was supported by the French Environment and Energy Management Agency (ADEME), the French Alternative Energies and Atomic Energy Commission (CEA) and the KIC InnoEnergy.

A part of the results presented in this paper have been obtained within the frame of the IWT SBO-110006 project The Next Generation Organic Rankine Cycles (www.orcnext.be), funded by the Institute for the Promotion and Innovation by Science and Technology in Flanders. This financial support is gratefully acknowledged.

\section{References}

[1] Manolakos D, Kosmadakis G, Kyritsis S, Papadakis G. Identification of behaviour and evaluation of performance of small scale, low-temperature organic Rankine cycle system coupled with a RO desalination unit. Energy 2009;34(6): 767-74.

[2] Kosmadakis G, Manolakos D, Papadakis G. An investigation of design concepts and control strategies of a double-stage expansion solar organic Rankine cycle. Int J Sustain Energy 2015;34(7):446-67.

[3] Schuster A, Karellas S, Aumann R. Efficiency optimization potential in supercritical organic Rankine cycles. Energy 2010;35(2):1033-9.

[4] Zanelli R, Favrat D. Experimental investigation of a hermetic scroll expandergenerator. Paper 1021. In: Presented at the international compressor engineering conference; 1994.

[5] Nguyen VM, Doherty PS, Riffat SB. Development of a prototype lowtemperature Rankine cycle electricity generation system. Appl Therm Eng 2001;21:169-81.

[6] Yamamoto T, Furuhata T, Arai N, Mori K. Design and testing of the organic Rankine cycle. Energy 2001;26:239-51.

[7] Kane M, Larrain D, Favrat D, Allani Y. Small hybrid solar power system. Energy 2003;28:1427-43.

[8] Yagoub W, Doherty P, Riffat SB. Solar energy-gas driven micro-CHP system for an office building. Appl Therm Eng 2006;26:1604-10.

[9] Manolakos D, Papadakis G, Kyritsis S, Bouzianas K. Experimental evaluation of an autonomous low-temperature solar Rankine cycle system for reverse osmosis desalination. Desalination 2007:203(1-3):366-74.

[10] Manolakos D, Kosmadakis G, Kyritsis S, Papadakis G. On site experimental evaluation of a low-temperature solar organic Rankine cycle system for RO desalination. Sol Energy 2009;83(5):646-56.

[11] Wang XD, Zhao L, Wang JL, Zhang WZ, Zhao XZ, Wu W. Performance evaluation of a low-temperature solar Rankine cycle system utilizing R245fa. Sol Energy 2010;84:353-64.

[12] Bryszewska-Mazurek A, Świeboda T, Mazurek W. Performance analysis of a solar-powered organic rankine cycle engine. J Air Waste Manag Assoc 2011;61:3-6. 
[13] Li J, Pei G, Li Y, Wang D, Ji J. Examination of the expander leaving loss in variable organic Rankine cycle operation. Energy Convers Manag 2013;65: 66-74.

[14] Chang JC, Chang CW, Hung TC, Lin JR, Huang KC. Experimental study and CFD approach for scroll type expander used in low-temperature organic Rankine cycle. Appl Therm Eng 2014;73(2):1444-52.

[15] Dumont O, Quoilin S, Lemort V. Design, modeling and experimentation of a reversible HP-ORC prototype. In: Presented at the ASME turbo expo 2014, Dusseldorf, Germany; June 2014. p. 16-20.

[16] Ntavou E, Kosmadakis G, Manolakos D, Papadakis G, Papantonis D. Experimental investigation of a small-scale two stage organic Rankine cycle engine operating at low temperature. In: Presented at the 3rd int. Seminar on ORC power systems (ASME-ORC2015), Brussels, Belgium; October 2015. p. 12-4.

[17] Leontaritis AD, Pallis P, Karellas S, Papastergiou A, Antoniou N, Vourliotis P, et al. Experimental study on a low temperature ORC unit for onboard waste heat recovery from marine diesel engines. In: Presented at the 3rd int Seminar on ORC power systems (ASME-ORC2015), Brussels, Belgium; October 2015. p. 12-4.

[18] Kolasiński P. The influence of the heat source temperature on the multivane expander output power in an organic Rankine cycle (ORC) system. Energies 2015;8:3351-69.

[19] Galloni E, Fontana G, Staccone S. Design and experimental analysis of a mini ORC (organic Rankine cycle) power plant based on R245fa working fluid. Energy 2015;90:768-75.

[20] Lemort V, Declaye S, Quoilin S. Experimental characterization of a hermetic scroll expander for use in a micro-scale Rankine cycle. Proc Inst Mech Eng A J Power Energy 2012;226(1):126-36.

[21] Quoilin S, Lemort V, Lebrun J. Experimental study and modeling of an organic Rankine cycle using scroll expander. Appl Energy 2010;87(4):1260-8.

[22] Walraven D, Laenen B, D'haeseleer W. Comparison of shell-and-tube with plate heat exchangers for the use in low-temperature organic Rankine cycles. Energy Convers Manag 2014;87:227-37.

[23] Shao LL, Yang L, Zhang CL. Comparison of heat pump performance using finand-tube and microchannel heat exchangers under frost conditions. Appl Energy 2010;87(4):1187-97.

[24] Kosmadakis G, Manolakos D, Olsson O, Ntavou E, Bystrom J, Papadakis G. Design and implementation of a hybrid low-concentration PV/thermal system, including a bottoming supercritical ORC engine. In: Presented at the 29th European PV solar energy conference and exhibition (29th EU PVSEC, 2014), Amsterdam, The Netherlands; September 2014. p. 22-6.

[25] Kosmadakis G, Manolakos D, Papadakis G. Experimental investigation of a low-temperature organic Rankine cycle (ORC) engine under variable heat input operating at both subcritical and supercritical conditions. Appl Therm Eng 2016;92(5):1-7.

[26] Maizza V, Maizza A. Unconventional working fluids in organic Rankine- cycles for waste energy recovery systems. Appl Therm Eng 2001;21(3):381-90.

[27] Kosmadakis G, Manolakos D, Bouzianas K, Papadakis G. Heat recovery in lowconcentration PV/thermal units using a low-temperature supercritical organic Rankine cycle for improved system performance. In: Presented at the 2nd int. Seminar on ORC power systems (ASME-ORC2013), Rotterdam, The Netherlands; October 2013. p. 7-8.

[28] Lazova M, Huisseune H, Kaya A, Lecompte S, Kosmadakis G, De Paepe M. Performance evaluation of a helical coil heat exchanger working under supercritical conditions in a solar organic Rankine installation. Energies 2016;9(6):432.

[29] Klein SA. Engineering equation solver (EES), academic professional version, FChart software. 2015.

[30] Landelle A, Tauveron N, Haberschill P, Revellin R, Colasson S. Study of reciprocating pump for supercritical ORC at full and part load operation. In: Presented at the 3rd int. seminar on ORC power systems (ASME-ORC2015), Brussels, Belgium; October 2015. p. 12-4.

[31] Dumont O, Quoilin S, Lemort V. Experimental investigation of a reversible heat pump/organic Rankine cycle unit designed to be coupled with a passive house to get a net zero energy building. Int J Refrig 2015;54:190-203.

[32] Declaye S, Quoilin S, Guillaume L, Lemort V. Experimental study on an open- drive scroll expander integrated into an ORC (organic Rankine cycle) system with R245fa as working fluid. Energy 2013;55:173-83.

[33] Quoilin S, Lemort V, Lebrun J. Experimental study and modeling of an organic Rankine cycle using scroll expander. Appl Energy 2010;87(4):1260-8.

[34] Song P, Wie M, Shi L, Danish SN, Ma C. A review of scroll expanders for organic Rankine cycle systems. Appl Therm Eng 2015:75(22):54-64.

[35] Zhu Y, Jiang L, Jin V, Yu L. Impact of built-in and actual expansion ratio difference of expander on ORC system performance. Appl Therm Eng 2014;71(1):548-58.

[36] Gao P, Jiang L, Wang LW, Wang RZ, Song ZP. Simulation and experiments on an ORC system with different scroll expanders based on energy and exergy analysis. Appl Therm Eng 2015;75:880-8.

[37] James F, Hellgardt K, Markides CN. An assessment of solar-powered organic Rankine cycle systems for combined heating and power in UK domestic applications. Appl Energy 2015;138(15):605-20.

38] Stijepovic MZ, Papadopoulos AI, Linke P, Grujic AS, Seferlis P. An exergy composite curves approach for the design of optimum multi-pressure organic Rankine cycle processes. Energy 2014;69:285-98.

[39] Baral Baral S, Kim D, Yun E, Kim K. Energy, exergy and performance analysis of small-scale organic Rankine cycle systems for electrical power generation applicable in rural areas of developing countries. Energies 2015;8:684-713.

[40] Borsukiewicz-Gozdur A. Exergy analysis for maximizing power of organic Rankine cycle power plant driven by open type energy source. Energy 2013:62:73-81.

\section{Nomenclature}

A: total heat transfer area $\left(\mathrm{m}^{2}\right)$

$C_{1}$ : pump parameter: VSD static losses (W)

$C_{2}$ : pump parameter: Motor part-load losses $\left(\mathrm{W}^{-1}\right)$

$C_{3}$ : pump parameter: Motor part-speed losses $\left(\mathrm{W} / \mathrm{rpm}^{2}\right)$

$C_{4}$ : pump parameter: Pump rotational friction $(\mathrm{W} / \mathrm{rpm})$

$C_{5}$ : pump parameter: Pumping efficiency $(-)$

E: exergy $(\mathrm{kW})$

$h$ : specific enthalpy $(\mathrm{J} / \mathrm{kg})$

$m$ : mass flow rate $(\mathrm{kg} / \mathrm{s})$

$P$ : Pressure (bar)

$Q$ : heat transfer $\left(\mathrm{kW}_{\mathrm{th}}\right)$

$s$ : specific entropy $(\mathrm{J} / \mathrm{kg} \mathrm{K})$

$T$ : Temperature $\left({ }^{\circ} \mathrm{C}\right)$

$V$ : volume flow rate $\left(\mathrm{m}^{3} / \mathrm{h}\right)$

$W$ : Power $(\mathrm{kW})$

$\eta$ : efficiency

$\Omega$ : rotational speed (rpm)

Subscript

$c d$ : condenser

el: electric (power)

esti: estimated (model)

evap: evaporator

exp: expander

hyd: hydraulic (power)

is: isentropic

in: inlet

meas: measured

mech: mechanical (power)

0 : heat sink

orc: organic fluid

out: outlet

pp: pump

sup: supply

th: therma 